\title{
Evolution of habitat and environment of red deer (Cervus elaphus) during the Late-glacial and early Holocene in eastern France (French Jura and the western Alps) using multi-isotope analysis $\left(\delta^{13} \mathrm{C}, \delta^{15} \mathrm{~N}, \delta^{18} \mathrm{O}, \delta^{34} \mathrm{~S}\right)$ of archaeological remains
}

\author{
D.G. Drucker ${ }^{\mathrm{a}, \mathrm{b}, *}$, A. Bridault ${ }^{\mathrm{c}}$, C. Cupillard ${ }^{\mathrm{d}}$, A. Hujic ${ }^{\mathrm{a}, \mathrm{b}}, \mathrm{H}$. Bocherens ${ }^{\mathrm{a}}$ \\ ${ }^{a}$ Fachbereich Geowissenschaften, Forschungsbereich Paläobiologie, Universität Tübingen, Hölderlinstr. 12, D-72074 Tübingen, Germany \\ ${ }^{\mathrm{b}}$ Fachbereich Geowissenschaften, Forschungsbereich Urgeschichte und Naturwisssenschaftliche Archäologie, Universität Tübingen, Rümelinstr. 23, D-72070 Tübingen, Germany \\ 'Equipe d'Archéologies Environnementales, Maison de l'Archéologie et de l'Ethnologie René Ginouvès, ArScAn-UMR 7041, case courrier 05, 21 allée de l'Université, \\ F-92023 Nanterre Cedex, France \\ d Service regional de l'Archéologie de France-Comté, 7 rue Charles Nodier, F-25043 Besançon Cedex, France; Laboratoire de Chrono-Environnement, UMR 6249, \\ UFR des Sciences et des Techniques, 16 route de Gray, F-25030 Besançon Cedex, France
}

\section{A B S T R A C T}

Red deer (Cervus elaphus) is a flexible species that survived the significant climatic and environmental change toward warming temperature and forested landscape of the Late-glacial to early Holocene transition (ca. 17-6 ka cal BP). To investigate the conditions of ethological adaptation of red deer at that time, isotopic analysis of carbon, nitrogen, sulfur in collagen $\left(\delta^{13} \mathrm{C}_{\text {coll }}, \delta^{15} \mathrm{~N}_{\text {coll }}, \delta^{34} \mathrm{~S}_{\text {coll }}\right)$ and of oxygen in phosphate $\left(\delta^{18} \mathrm{O}_{\mathrm{p}}\right)$ were performed on red deer from archaeological sites of the French Jura and the western Alps. Fifty out of eighty two samples benefited from direct AMS radiocarbon dating, which confirmed the few number of red deer record during the cold Younger Dryas oscillation (ca. 12.8 -11.6 ka cal BP) in Western Europe. The French Jura red deer showed a significant decrease in their $\delta^{13} \mathrm{C}_{\text {coll }}$ values and increase in their $\delta^{15} \mathrm{~N}_{\text {coll }}$ values in the early Holocene compared to the Late-glacial, which is most likely due to the change in environment from open areas with low pedogenic activity to warm dense forests with increasing soil maturity. In contrast, the stable $\delta^{13} \mathrm{C}_{\text {coll }}$ and $\delta^{15} \mathrm{~N}_{\text {coll }}$ values over time in the western Alps were thought to indicate a change to higher altitude for the red deer habitat in this mountainous region. A decrease of the $\delta^{18} \mathrm{O}_{\mathrm{p}}$ values between the Late-glacial and the early Holocene was observed in the western Alps red deer, in contrast to the expected increase with rising temperature which was indeed confirmed for the French Jura red deer. The multi-isotope results pointed to open areas home range at higher altitude for the Alps red deer in the Holocene compared to the previous period. The similarity of the $\delta^{34} S_{\text {coll }}$ patterns with those of the $\delta^{15} N_{\text {coll }}$ suggested the primarily influence of soil activity on the ${ }^{34} \mathrm{~S}$ abundances recorded by red deer in a purely terrestrial context. Red deer of the French Jura on one hand and of the western Alps on the other hand showed different adaptive response to the global warming of the early Holocene, with an ethological change in the first case and a change in home range in the second case.

\section{Introduction}

The Late-glacial to early Holocene transition, from ca. 17 to 6 ka cal BP, was marked by significant climatic change leading to a global warming, and the development of temperate landscape and faunal recomposition in western Europe. The succession of

\footnotetext{
* Corresponding author. Fachbereich Geowissenschaften, Forschungsbereich Paläobiologie, Universität Tübingen, Hölderlinstr. 12, D-72074 Tübingen, Germany. E-mail address: dorothee.drucker@ifu.uni-tuebingen.de (D.G. Drucker).
}

rapid oscillations between warm (interstadial) and cold (stadial) events before the final global warming of the early Holocene is now extensively documented through oxygen-isotope investigation on ice-cores from Greenland (Björck et al., 1998; Lowe et al., 2008). As a result, the vegetation composition changed from steppe-tundra during the Oldest Dryas (ca. 17.0-14.7 ka cal BP) to temperate dense deciduous forest that developed by the end of the Preboreal (ca. 11.6-10.0 ka cal BP). Stadial episodes were reflected by the development of herbaceous vegetation during the Younger Dryas (ca. 12.8-11.6 ka cal BP), and interstadial episodes corresponded to 
the development of pine-birch forest during the Bölling/Alleröd (ca. 14.7-12.8 ka cal BP) and Preboreal (e.g. Amman and Lotter, 1989; De Beaulieu et al., 1994). A major change also occurred in the faunal composition with the extinction of megafaunal species inherited from the Pleniglacial, such as woolly rhinoceros (Coelodonta antiquitas), giant deer (Megaloceros giganteus) and mammoth (Mammuthus primigenius) in Western Europe (e.g. Stuart et al., 2004). Other glacial species such as reindeer (Rangifer tarandus) were extirpated from most regions of northwestern Europe including eastern France (Bridault et al., 2000), while temperate species such as red deer (Cervus elaphus) and roe deer (Capreolus capreolus) increased in abundance (e.g. Sommer et al., 2008a, 2008b).

Species that survived the climatic changes and the vegetation modifications of this period offer the opportunity to track potential habitat change using phenotypic indicators. Stable isotopic composition of carbon, nitrogen, sulphur and oxygen in fossil bones are some of these ecological tracers. Among these species, red deer (C. elaphus) is an opportunistic mixed feeder and is able to live in variable habitat from open steppe to closed temperate forest (Heptner et al., 1989; Geist, 1999). The question that this paper will attempt to answer is, which strategy did red deer use to survive the global warming of the early Holocene? Eastern France offers a favorable context to document ecological changes in this large ungulate in different topographical contexts. French Jura and the western Alps exhibit contrasted altitudinal ranges that could have triggered different ecological responses of red deer facing warming. Isotopic trackers offer the opportunity to investigate several aspect of mammal, and especially red deer, ecology as reviewed in the following paragraphs.

\section{Habitat and environmental tracking using carbon-13}

The carbon-13 abundances $\left(\delta^{13} \mathrm{C}\right)$ of herbivore tissues reflect those of plants, which depend on the source of atmospheric carbon and the photosynthetic process (review in Tieszen, 1991; Heaton, 1999). In Western Europe, ancient and modern indigenous plants exhibit a $C_{3}$ photosynthesis pattern, and their $\delta^{13} \mathrm{C}$ values vary according to environmental conditions, especially water availability. Recent studies confirmed a positive correlation between the discrimination against ${ }^{13} \mathrm{C}$ in plants and mean annual precipitation (MAP) leading to the decrease of plant $\delta^{13} \mathrm{C}$ values when the MAP increases (Diefendorf et al., 2010; Kohn, 2010). Light intensity, temperature, salinity and short term change in the atmospheric $\mathrm{CO}_{2}$ pressure $\left(\mathrm{pCO}_{2}\right)$ can also induce variation in plant $\delta^{13} \mathrm{C}$ values through stomatal conductance, water use efficiency (WUE) and photosynthetic intensity control (review in Tieszen, 1991; Heaton, 1999; Dawson et al., 2002). Plant $\delta^{13} \mathrm{C}$ values increase with altitude as the result of increasing WUE with lower temperature and partial atmospheric $\mathrm{pCO}_{2}$ (e.g. Farquhar et al., 1989; Morecroft and Woodward, 1990; Körner et al., 1991; Hultine and Marshall, 2000). Landscape closure is another important source of variation in plant $\delta^{13} \mathrm{C}$ values since plants that develop under close canopies present depleted $\delta^{13} \mathrm{C}$ values compared to the same plant form growing in more open conditions (review in Tieszen, 1991; Heaton, 1999; Dawson et al., 2002). Concentration of recycled $\mathrm{CO}_{2}$ due to poorly ventilated air, light attenuation and relative high water availability in closed canopy forest are evoked to explain the so-called "canopy effect". (e.g. Gebauer and Schultze, 1991; van der Merwe and Medina, 1991; Broadmeadow et al., 1992). Altitude and canopy effect leading to change in $\delta^{13} \mathrm{C}$ values of plants are passed on to collagen values of herbivores, as it was confirmed by data from modern ecosystems (e.g. Männel et al., 2007; Drucker et al., 2008, 2010). Thus, herbivores dwelling and foraging in at low altitude and/or in dense forest are expected to have $\delta^{13} C_{\text {coll }}$ values relative lower than those of their counterparts living at higher altitude and/ or in more open habitat.

\section{Habitat and environmental tracking using nitrogen-15}

The nitrogen isotopic composition of bone collagen $\left(\delta^{15} \mathrm{~N}\right)$ from herbivores depends on dietary, physiological and climatic parameters. The enrichment in ${ }^{15} \mathrm{~N}$ during the first months of life due to the consumption of animal protein through maternal milk was convincingly documented in herbivores (e.g. Jenkins et al., 2001). For adults, seasonal change in diet composition, nutritional quality of the forage and physiological status (pregnancy, lactation) can significantly impact the $\delta^{15} \mathrm{~N}$ values of tissues (e.g. Barnett, 1994; Sponheimer et al., 2003a, 2003b; Barboza and Parker, 2006). The effect of such punctual changes on isotopic signature can be retained in dentine collagen coming from tooth roots, which grow on short period of time and are not remodeled once completely formed (e.g. Balasse et al., 2001; Britton, 2009; Drucker et al. in press). In contrast, bone collagen is reflecting long-term isotopic trend as bone is continuously remodeled with a turnover of several years over life (review in Koch, 2007). Thus, bone $\delta^{15} \mathrm{~N}_{\text {coll }}$ values of mature individuals of a given species are more sensitive to environmental change through long time periods. Temperature and aridity are mostly quoted as climatic parameters driving significant changes in $\delta^{15} N_{\text {coll }}$ values of herbivores as a result of change in $\delta^{15} \mathrm{~N}$ values of foraged plants in modern and ancient ecosystems (e.g. Iacumin et al., 2000; Drucker et al., 2003a; Murphy and Bowman, 2006; Stevens et al., 2006). In Western Europe during the last 40,000 years, the chronological and geographical variation in $\delta^{15} \mathrm{~N}_{\text {coll }}$ values of large herbivore seemed to follow the intensity of soil activity driven by temperature and glacier occurrence (Drucker et al., 2003a, 2003b; Stevens et al., 2008). A previous study focused on the Late-glacial and early Holocene red deer from the Rochedane site in Jura has confirmed the relation between increasing $\delta^{15} \mathrm{~N}_{\text {coll }}$ values and rising temperature over time (Drucker et al., 2009). Implied mechanism most probably involved increasing nitrogen cycling process in soils since a positive relation was found between ${ }^{15} \mathrm{~N}$ abundances in plants and pedogenic activity (e.g. Hobbie et al., $1998,2005)$. The same mechanism can also explain the lower $\delta^{15} \mathrm{~N}$ values of herbivores, plants and soils observed with higher altitude in modern ecosystems (e.g. Mariotti et al., 1980; Männel et al., 2007). Hence, the $\delta^{15} \mathrm{~N}$ values of the red deer considered in this study should reflect change in global temperature over time and local altitude at a given period of time.

\section{Habitat and environmental tracking using oxygen-18}

Oxygen isotopic $\left(\delta^{18} \mathrm{O}\right)$ values in the phosphate fraction of bone relate to those of ingested water for large mammals (e.g. Longinelli, 1984; Iacumin et al., 1996; Kohn et al., 1996). In the case of red deer, the $\delta^{18} \mathrm{O}$ values of bone phosphate reflect those of the local precipitation (D'Angela and Longinelli, 1990; Iacumin et al., 1996). This results points to the main contribution of drinking water and the negligible influence of relative humidity in the oxygen isotopic signature of red deer. The $\delta^{18} \mathrm{O}$ value of meteoric water reflects essentially the temperature in boreal and temperate contexts (Fricke and O'Neil, 1999). A consistent pattern was found in modern red deer between intra-tooth variations in phosphate $\delta^{18} \mathrm{O}$ values and seasonal change in temperature (Fricke et al., 1998). In the context of eastern France during the Late-glacial and early Holocene, $\delta^{18} \mathrm{O}$ values of meteoric water are predicted to decrease with lower temperatures and higher altitudes. In areas with important altitudinal gradients, it would be possible to track the altitude at which the studied animals obtained their drinking water at a given period of time. 


\section{Habitat and environmental tracking using sulphur-34}

The sulfur isotopic values $\left(\delta^{34} S\right)$ of the diet are passed on to a consumer's tissues, such as bone, with almost no fractionation effect (Richards et al., 2001). The measurement of $\delta^{34} S$ of bone and tooth collagen has recently been developed and its application on archaeological material was first devoted to the distinction between aquatic and terrestrial sources in diet (e.g. Richards et al., 2001; Craig et al., 2006; Privat et al., 2007). While marine ecosystems are characterized by rather uniform high $\delta^{34} \mathrm{~S}$ values (ca. $+20 \%$ ), freshwater and terrestrial ecosystems display more variable $\delta^{34} S$ values as the result of the environmental parameters, such as bedrock weathering, atmospheric deposition and microbial processes (Peterson and Fry, 1987). The possible discrimination in $\delta^{34} \mathrm{~S}_{\text {coll }}$ values among geographical origins of diet sources was also mentioned (Vika, 2009; Craig et al., 2010). Studies on modern herbivores have confirmed that the natural abundance in ${ }^{34} \mathrm{~S}$ in unpolluted plants is essentially a function of distance from the sea and geology of the local area (e.g. Rossmann et al., 2000; Camin et al., 2007). A recent work from Britton (2009) has shown contrasted collagen $\delta^{34} \mathrm{~S}$ values in modern reindeer and bison, which are correlated with strontium isotope ratios, a direct indicator of geological context. The potential of sulphur isotope analyses as a tracker of geographical origin was suggested in studies of human remains from archaeological sites as a result of local geology contrast and proximity of the sea (Vika, 2009; Craig et al., 2010). So far, there was no sulfur isotope investigation based on herbivores from continental ecosystems, where marine influence through sea spray effect is insignificant and pollution by industrial activity inexistent. It is hypothesized that in such conditions, the $\delta^{34} \mathrm{~S}$ values passed to herbivore through plants should reflect contrast in local geology and soil microbial activity.

The present study aims to (1) evaluate the change in habitat and pedogenic activities through time reflected by the collagen $\delta^{13} \mathrm{C}$ and $\delta{ }^{15} \mathrm{~N}$ values of red deer from French Jura in contrast to French Alps, (2) to consider the temporal trends in $\delta^{18} \mathrm{O}$ values in phosphate fraction of skeletal remains for red deer in French Jura and Alps (3) to explore the collagen $\delta^{34} \mathrm{~S}$ values as a potential marker of mobility of red deer in both regions.

\section{Material and methods}

Sixty-two skeletal parts of red deer (C. elaphus) were selected from nine archaeological sites of French Jura $(n=62$, Table 1, Fig. 1 ; Pétrequin, 1970; Thévenin and Sainty, 1980; Thévenin, 1982; Vuaillat et al., 1984; Campy et al., 1989; Pion et al., 1990; Aimé, 1993; Cupillard and David, 1995; Cupillard et al., 2000; Pion, 2004; Voruz et al., 2004; Cupillard, 2008). In addition, twenty red deer remains from five stratified sites located in the neighboring region of the western Alps were considered (Table 1, Fig. 1; Chaffenet and Cordier, 1999; Bintz and Pelletier, 2000; Nicod and Picavet, 2003; Pion and Mével, 2005). In both cases, identified anatomical parts were sampled and bones were favored to teeth in order to access to a time-life record. Tooth root was analyzed in only two cases, for which the nitrogen-15 abundances were not retained because of the possible interference caused by the suckling effect, as previously mentioned. For the same reason, bones of mature individuals were systematically chosen. In some cases, different individuals from the same site were sampled by selecting the same anatomical part.

New direct AMS radiocarbon $\left({ }^{14} \mathrm{C}\right)$ dating were performed on fifteen red deer samples from French Jura in addition to those already available on other red deer bones included in this study (Table S1). The results were calibrated at 2 sigma based on the intcal09.14C calibration dataset and calculated by CALIB REV6.0.0 program (Reimer et al., 2009). Corresponding chronological phases were indicated using pollen chronozone succession based on studies in Jura (Table S1 and S2; Richard and Bégeot, 2000; Magny et al., 2006) and NGRIP isotopic record stratigraphy (Table S1; Lowe et al., 2008). Chronological attribution were assigned to undated samples based on the AMS ${ }^{14} \mathrm{C}$ dates obtained on the red deer remains from the same levels for the sites of French Jura and on published ${ }^{14} \mathrm{C}$ dating of the archaeological deposits for the sites of the western Alps (Table S2).

Collagen was extracted following a protocol based on Longin (1971) and modified by Bocherens et al. (1997). The extraction process includes a step of soaking in $0.125 \mathrm{M} \mathrm{NaOH}$ between the demineralization and solubilization steps to achieve the elimination of lipids. Elemental analysis $\left(\mathrm{C}_{\text {coll }}, \mathrm{N}_{\text {coll }}, \mathrm{S}_{\text {coll }}\right)$ and isotopic analysis $\left(\delta^{13} \mathrm{C}_{\text {coll }}, \delta^{15} \mathrm{~N}_{\text {coll }}, \delta^{34} \mathrm{~S}_{\text {coll }}\right)$ were conducted at the Department of Geosciences of Tübingen University using a NC2500 CHNelemental analyzer coupled to a Thermo Quest Delta + XL mass spectrometer. The standard, internationally defined, is a marine carbonate (PDB) for $\delta^{13} \mathrm{C}$ and atmospheric nitrogen (AIR) for $\delta^{15} \mathrm{~N}$. Analytical error, based on within-run replicate measurement of laboratory standards (albumen, modern collagen, USGS 24, IAEA $305 \mathrm{~A}$ ), was $\pm 0.1 \%$ or for $\delta^{13} \mathrm{C}$ values and $\pm 0.2 \%$ or $\delta^{15} \mathrm{~N}$ values. Samples were calibrated to $\delta^{34} \mathrm{~S}$ values relative to CDT of NBS 123 $\left(\delta^{34} \mathrm{~S}=17.10 \%\right)$, NBS $127 \quad\left(\delta^{34} \mathrm{~S}=20.31 \%\right)$, IAEA-S-1 $\left(\delta^{34} \mathrm{~S}=-0.30 \%\right)$ and IAEA-S-3 $\left(\delta^{34} \mathrm{~S}=21.70 \%\right)$. The reproducibility is $\pm 0,4 \%$ for $\delta^{34} \mathrm{~S}$ measurements, and the error on amount of $\mathrm{S}$ measurement is $5 \%$. Reliability of the $\delta^{13} \mathrm{C}_{\text {coll }}$ and $\delta^{15} \mathrm{~N}_{\text {coll }}$ values can be established by measuring its chemical composition, with $\mathrm{C} /$ $\mathrm{N}_{\text {coll }}$ atomic ratio ranging from 2.9 to 3.6 (DeNiro, 1985), percentage of $C_{\text {coll }}$ and $N_{\text {coll }}$ above $8 \%$ and $3 \%$, respectively (Ambrose, 1990). The $\delta^{34} \mathrm{~S}$ values of samples with atomic $\mathrm{C} / \mathrm{S}_{\text {coll }}$ and $\mathrm{N} / \mathrm{S}_{\text {coll }}$ ratios in the

Table 1

List of the studied archaeological sites from the French Jura and the western Alps with their geographical location and altitude.

\begin{tabular}{|c|c|c|c|c|c|c|}
\hline Site & Locality & District & Region (district) & Altitude (m) & Lab code & $\mathrm{N}^{\circ}$ in Fig. 1 \\
\hline Mannlefelsen I & Oberlarg & Haut-Rhin & French Jura & 550 & OB- & 1 \\
\hline La Baume & Gonvillars & Haute-Saône & French Jura & 388 & GNV- & 2 \\
\hline Sous la Roche & Bavans & Doubs & French Jura & 275 & BVN- & 3 \\
\hline Rochedane & Villars-sous-Dampjoux & Doubs & French Jura & 355 & RCD- & 4 \\
\hline La Baume de Montandon & Saint-Hippolyte & Doubs & French Jura & 590 & STH- & 5 \\
\hline Gigot 1 and 2 & Bretonvillers & Doubs & French Jura & 457 & BRT- & 6 \\
\hline Les Cabônes & Ranchot & Jura & French Jura & 216 & RAN- & 7 \\
\hline La Baume & Gigny-sur-Suran & Jura & French Jura & 485 & GIS- & 8 \\
\hline Le Gardon & Ambérieu-en-Bugey & Ain & French Jura & 373 & GAR- & 9 \\
\hline Les Douattes & Musièges & Haute-Savoie & western Alps & 370 & LDT- & 10 \\
\hline La Fru & St-Christophe-la-Grotte & Savoie & western Alps & 570 & FRU- & 11 \\
\hline Aulp du Seuil & St-Bernard-du-Touvet & Isère & western Alps & 1700 & APS- & 12 \\
\hline La Grande Rivoire & Sassenage & Isère & western Alps & 580 & GRV- & 13 \\
\hline Les Corréardes & Lus-la-Croix-Haute & Drôme & western Alps & 1070 & LUS- & 14 \\
\hline
\end{tabular}


range of 300-900 and 100-300, respectively (Nehlich and Richards, 2009) were retained.

The $\delta^{18} \mathrm{O}$ analyses of phosphate were performed at the Department of Geosciences (University Tübingen, Germany). Prior to these analyses of the bone phosphate fraction, bone powders were chemically pre-treated with $2 \% \mathrm{NaOCl}$ solution, followed by a $1 \mathrm{M}$ Ca-acetate from acetic acid buffer solution (Bocherens et al., 1996). Oxygen isotope composition of phosphate $\left(\delta^{18} \mathrm{O}_{\mathrm{p}}\right)$ was measured on silver phosphate $\left(\mathrm{Ag}_{3} \mathrm{PO}_{4}\right)$. About $4 \mathrm{mg}$ of pre-treated powder were dissolved in $2 \mathrm{M} \mathrm{HF}$, neutralized with $\mathrm{NH}_{4} \mathrm{OH}$ and the $\mathrm{PO}_{4}$ in solution was rapidly precipitated as $\mathrm{Ag}_{3} \mathrm{PO}_{4}$ by adding $2 \mathrm{M} \mathrm{AgNO}_{3}$ according to the method described in Tütken et al. (2006). $\mathrm{Ag}_{3} \mathrm{PO}_{4}$ of each sample and standard was analysed in triplicate $(\sim 500 \mu \mathrm{g}$ for a single measurement) for $\delta^{18} \mathrm{O}_{\mathrm{p}}$. The $\delta^{18} \mathrm{O}_{\mathrm{p}}$ measurements were performed using a Finnigan TC-EA at $1450{ }^{\circ} \mathrm{C}$ linked via a Finnigan Conflow III to a ThermoFinnigan Delta Plus XL CFIRMS at the University of Tübingen with a reproducibility of $\pm 0.3 \%$. Samples are calibrated to $\delta^{18} \mathrm{O}$ values of TU-1 $\left(\delta^{18} \mathrm{O}=21.11 \%\right.$, relatively to VSMOW $)$; TU-2 $\left(\delta^{18} \mathrm{O}=5.35 \%\right.$, relatively to VSMOW $) ; 130-0.5-1$ $\left(\delta^{18} \mathrm{O}=-1.13 \%\right.$, relatively to VSMOW $)$ and $130-0.5-9$ $\left(\delta^{18} \mathrm{O}=8.42 \%\right.$, relatively to VSMOW $)$.

\section{Results and discussion}

\subsection{Chronological distribution of red deer}

When considering the fifty direct radiocarbon AMS dates obtained so far (Table S1), a gap was observed for red deer from French Jura and northern Alps for the most part of the Younger Dryas (Fig. 2). The absence of data could be due either to the scarcity of this species during this period or to the lack of preservation of archaeological deposits as the result of the harsh climatic conditions during the Younger Dryas in Jura. Since the development of systematic radiocarbon dating of a given species, some temporal gaps have been documented especially around the Last Glacial Maximum (ca. 29.0-18.5 ka cal BP) for carnivores, such as the cave lion (Panthera spelaea), and for large herbivores such as giant deer and mammoth (Stuart et al., 2004; Stuart and Lister, 2010). These gaps have been interpreted as the reflection of local extirpation and possible bottleneck events. Sommer et al. (2008b) noted the small number of direct evidence of red deer during the Younger Dryas (GS-1) in northwestern Europe. This decrease in red deer record was considered to be the result of the harsh climatic conditions and
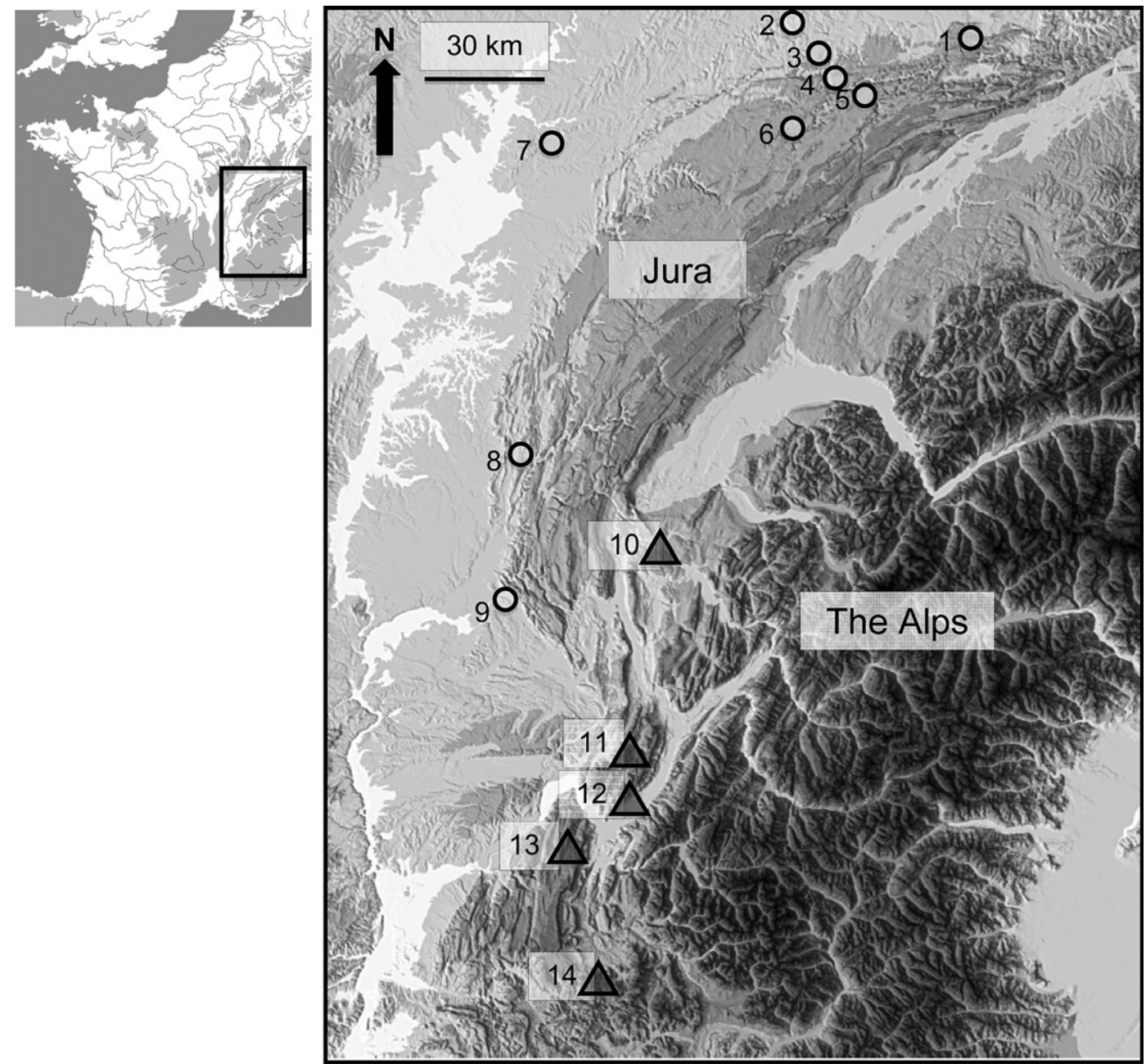

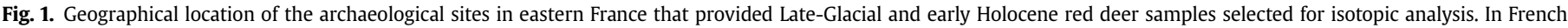

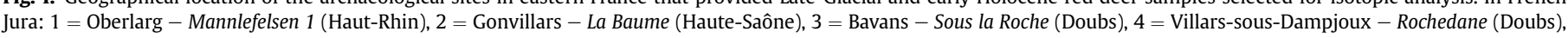

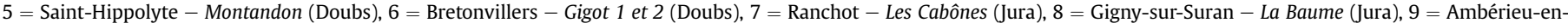

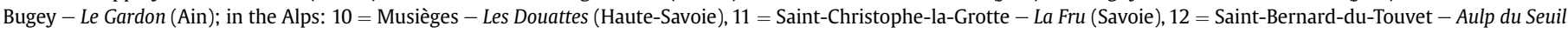
(Isère), 13 = Sassenage - La Grande Rivoire (Isère), 14 = Lus-la-Croix-Haute - Les Corréardes (Drôme). 


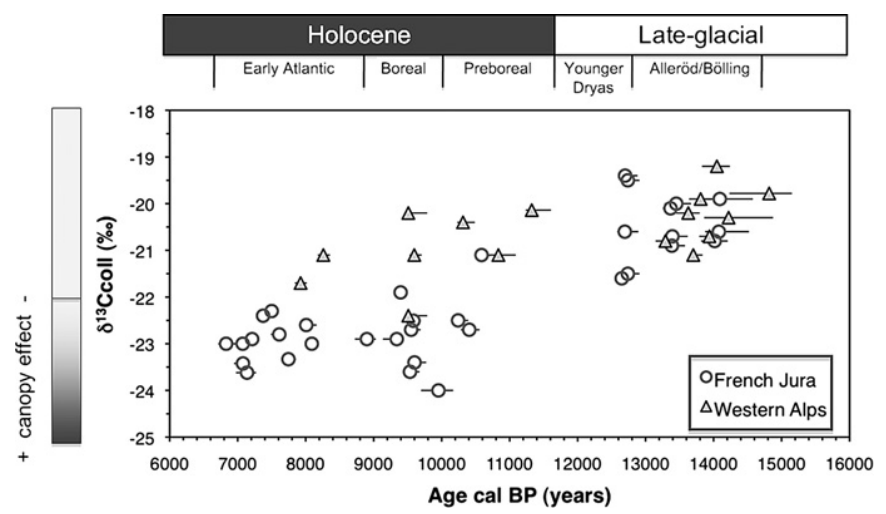

Fig. 2. The $\delta^{13} \mathrm{C}_{\text {coll }}$ values of AMS dated red deer (Cervus elaphus) from the French Jura (white circles) and the western Alps (gray triangles) against time through the Lateglacial to early Holocene transition. Values below ca. $-22 \%$ are interpreted as the result of the canopy effect. The AMS results were calibrated at based on intcal09.14C calibration dataset and calculated by CALIB REV6.0.0 program (Reimer et al., 2009).

the disappearance of the interstadial forest, which would have favored the cold-adapted reindeer. A larger dataset of dates on red deer as well as on archaeological contexts in the French Jura and the western Alps would be necessary to confirm the observed temporal gap and to interpret it in terms of prey distribution.

\subsection{Carbon-13 and canopy development in French Jura and western Alps}

The red deer $\delta^{13} \mathrm{C}_{\text {coll }}$ values varied from -24.0 to $-19.4 \%$ in Jura (Table 2) and from -22.4 to $-18.7 \%$ in the Alps (Table 3 ) during the Late-glacial and early Holocene. Directly dated red deer from Jura showed a clear decrease in $\delta^{13} C_{\text {coll }}$ values over time, as previously observed in Drucker et al. (2008) on a more limited number of specimens (Fig. 2). Before the onset of the early Holocene (ca. $11.6 \mathrm{ka}$ cal BP), Jura red deer yielded relatively high $\delta^{13} \mathrm{C}$ values (from -21.6 to $-19.4 \%$ ), which were comparable to those of red deer from the Alps $(-21.1$ to $-19.2 \%$ ). In the beginning of the Holocene, the Preboreal period (ca. 11.6-10.0 ka cal BP) exhibited an initial decrease in $\delta^{13} \mathrm{C}_{\text {coll }}$ values of red deer in Jura with a range of -22.7 to $-21.1 \%$. Later, Jura red deer had $\delta^{13} C_{\text {coll }}$ values ranging from -24.0 to $-21.9 \%$, which are lower than the values of those observed during the Late-glacial as well as those measured on the early Holocene red deer from the Alps (from -22.4 to $-20.1 \%$ ). The decrease of $\delta^{13} \mathrm{C}_{\text {coll }}$ values of red deer from Jura was previously described and interpreted as the result of habitat change from open to closed habitat (Drucker et al., 2003b, 2008). Some authors insisted on the effect of increase in atmospheric $\mathrm{pCO}_{2}$ between the Late-glacial and the Holocene to explain a comparable decrease in $\delta^{13} C_{\text {coll }}$ values of horse in northern Europe (Richards and Hedges, 2003; Stevens and Hedges, 2004). However, plants were found to maintain a stable $\delta^{13} \mathrm{C}$ values while they were facing long-term change in atmospheric $\mathrm{CO}_{2}$ thanks to their capacity to adapt their stomatal conductance (see Arens et al., 2000). Therefore, $\delta^{13} \mathrm{C}$ value of atmospheric $\mathrm{CO}_{2}$ has a more significant impact on plant $\delta^{13} \mathrm{C}$ values over time (Arens et al., 2000). Between the post Last Glacial Maximum and the Holocene, a decrease of up to $0.5 \%$ in the atmospheric $\mathrm{CO}_{2} \delta^{13} \mathrm{C}$ value was reconstructed from fossil plant remains (Marino et al., 1992) and thus cannot entirely explain the mean $\delta^{13} C_{\text {coll }}$ decrease of $2.3 \%$ observed for the Jura red deer. Temperature was another quoted factor that could influence the ${ }^{13} \mathrm{C}$ amounts of red deer as a negative correlation was observed between the $\delta^{13} \mathrm{C}_{\text {coll }}$ values of modern deer and the mean annual maximum temperatures (Stevens et al., 2006). However, different pattern of ${ }^{13} \mathrm{C}$ decrease was found among ungulate species in the Paris Basin at the Late-Glacial/early Holocene transition, which could hardly be explained by the sole impact of a global environmental parameter such as temperature (Drucker et al., 2008). Moreover, the effect of temperature change on carbon isotope fractionation in plants can be considered as minor (Diefendorf et al., 2010; Kohn, 2010). Altitudinal effect in Jura could not either account alone for the decrease in red deer $\delta^{13} \mathrm{C}_{\text {coll }}$ value, since it would imply a difference of at least 2,000 $\mathrm{m}$ between the dwelling areas of red deer over time, a value that exceeds the whole altitudinal range found in the Jura mountains. Finally, the canopy effect appears to be the most likely explanation of the significant depletion in red deer $\delta^{13} \mathrm{C}$ values at the Late-glacial/early Holocene transition in Jura.

The review of the $\delta^{13} \mathrm{C}_{\text {coll }}$ values from directly and indirectly dated red deer samples from Jura (Fig. 3) confirmed the trend of significant decrease between the Late-glacial and the early Holocene periods, with a possible intermediate step during the Preboreal (Fig. 3). The change of red deer habitat toward dense forested areas in Jura, reflected by $\delta^{13} \mathrm{C}_{\text {coll }}$ values lower than $-22 \%$ (Drucker et al., 2008), seemed to take place by the end of the Preboreal. In contrast, the red deer $\delta^{13} \mathrm{C}_{\text {coll }}$ values in the Alps were rather stable over time (Fig. 3). Most of the values are comprised between -21.1 and $-19.2 \%$. As a result the red deer exhibited significantly less negative values in the Alps than in Jura during the early Holocene (Mann-Whitney-Wilcoxon test, $p<0.0001$ ). Thus, the habitat of red deer in the Alps did not reflect a significant canopy effect. This absence of canopy effect could be a consequence of higher altitude and/or lower degree of canopy density in the Alps than in Jura. Interestingly, one specimen from a high altitude site in the Alps (LUS-2 from Les Corréardes) yielded a $\delta^{13} \mathrm{C}_{\text {coll }}$ value of $-18.7 \%$ during the early Atlantic, which is $2.5 \%$ higher than the mean values of the coeval red deer of the same region. For a raise of $1000 \mathrm{~m}$ in altitude, an increase in $\delta^{13} \mathrm{C}$ value of about $1.1 \%$ was measured in plants as the result of increasing water use efficiency along altitudinal gradient (e.g. Körner et al., 1991; Männel et al., 2007). Such a rate of $\delta^{13} \mathrm{C}$ increase with altitude would imply a difference of about $2300 \mathrm{~m}$ of altitude between the dwelling area of LUS-2 specimen and those of the red deer from the other Alpine sites. Such an altitudinal contrast is larger than the actual difference of altitude among the considered sites and their surroundings, which corresponds to the Prealps range. Therefore, a slight influence of understory vegetation from dense forest could be suspected in the Alps, especially as a significant decrease in the early Holocene was detected when the LUS-2 specimen, most likely from high altitude territory, was excluded (Mann-Whitney-Wilcoxon test, $p<0.05$ ). Either the forest stands of the Alps were less dense than in Jura and/or the red deer hunted in the Alps were consuming only occasionally understory vegetation from closed woodland.

\subsection{Nitrogen-15, soil development and altitude of habitat}

Dated collagen of the red deer from Jura exhibited a dramatic increase in $\delta^{15} \mathrm{~N}$ values in the early Holocene (3.4-7.8\% ) compared to the Late-glacial $\left(0.8-3.8 \%\right.$ ) (Table 2, Fig. 4). As for the $\delta^{13} C_{\text {coll }}$ values, the Preboreal red deer provided intermediate $\delta^{15} \mathrm{~N}_{\text {coll }}$ values compared to those of the Late-Glacial on one hand and those of the Boreal and early Atlantic on the other hand. The trend in increasing $\delta^{15} \mathrm{~N}_{\text {coll }}$ values of Jura red deer followed the trend in increasing temperature due to the global warming witnessed during the Lateglacial to early Holocene transition. Enhanced biological activity linked to soil development leads to ${ }^{15} \mathrm{~N}$ enrichment in soils and plants through the intensification of nitrogen turnover (e.g. Nadelhoffer and Fry, 1994; Hobbie et al., 2005). The increase in pedogenic activities during the early Holocene is evidenced by the increase in plant biomass linked to the development of temperate 
Table 2

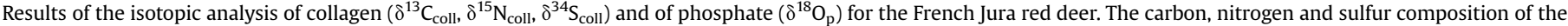

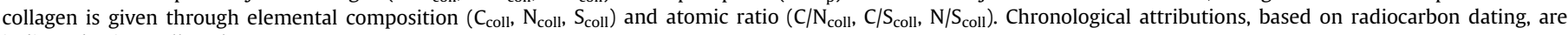
indicated using pollen chronozone.

\begin{tabular}{|c|c|c|c|c|c|c|c|c|c|c|c|}
\hline $\mathrm{Lab} \mathrm{n}^{\circ}$ & $\mathrm{C}_{\text {coll }}(\%)$ & $\mathrm{N}_{\text {coll }}(\%)$ & $\mathrm{C} / \mathrm{N}_{\text {coll }}$ & $\delta^{13} C_{\text {coll }}(\%)$ & $\delta^{15} \mathrm{~N}_{\text {coll }}(\%)$ & $\mathrm{S}_{\text {coll }}(\%)$ & $\mathrm{C} / \mathrm{S}_{\text {coll }}(\%)$ & $\mathrm{N} / \mathrm{S}_{\text {coll }}(\%)$ & $\delta^{34} S_{\text {coll }}(\%)$ & $\delta^{18} \mathrm{O}_{\mathrm{p}}(\% \mathrm{oo})$ & Pollen chronozone \\
\hline BVN-2 & 37.9 & 13.3 & 3.3 & -23.0 & 7.1 & 0.15 & 656 & 197 & 8.6 & 15.8 & Early Atlantic \\
\hline BVN-1 & 31.5 & 12.3 & 3.0 & -23.5 & 7.5 & - & - & - & - & 16.2 & Early Atlantic \\
\hline GNV 3 & 40.4 & 14.1 & 3.3 & -23.0 & 6.5 & - & - & - & - & - & Early Atlantic \\
\hline GNV-6 & 39.7 & 15.2 & 3.0 & -23.4 & 7.1 & 0.16 & 676 & 222 & 8.5 & - & Early Atlantic \\
\hline RCD-10500 & 42.2 & 16.5 & 3.0 & -23.6 & 4.8 & 0.19 & 599 & 201 & 8.4 & 16.6 & Early Atlantic \\
\hline RCD-10600 & 40.7 & 15.1 & 3.1 & -22.3 & 6.0 & 0.16 & 688 & 219 & 8.8 & 16.8 & Early Atlantic \\
\hline RCD-10700 & 40.6 & 14.9 & 3.2 & -23.7 & 5.5 & - & - & - & - & 16.5 & Early Atlantic \\
\hline GIS-1 & 41.9 & 16.6 & 2.9 & -22.9 & 6.4 & 0.16 & 711 & 242 & 8.1 & - & Early Atlantic \\
\hline STH-1 & 43.7 & 16.4 & 3.1 & -22.4 & 5.9 & 0.15 & 753 & 242 & 10.3 & - & Early Atlantic \\
\hline GAR-1 & 39.7 & 14.6 & 3.2 & -21.7 & 4.7 & - & - & - & - & - & Early Atlantic \\
\hline OB-15 & 42.5 & 14.9 & 3.3 & -22.3 & 5.6 & 0.18 & 617.2 & 185.5 & 10.0 & - & Early Atlantic \\
\hline RCD-10100 & 37.4 & 13.5 & 3.2 & -22.8 & 5.8 & - & - & - & - & 15.6 & Early Atlantic \\
\hline RCD-10200 & 38.2 & 14.2 & 3.1 & -22.7 & 4.3 & - & - & - & - & 15.7 & Early Atlantic \\
\hline RCD-10300 & 38.1 & 14.0 & 3.2 & -22.9 & 6.4 & - & - & - & - & 17.2 & Early Atlantic \\
\hline RCD-10400 & 37.7 & 13.7 & 3.2 & -22.6 & 4.2 & - & - & - & - & 17.1 & Early Atlantic \\
\hline BVN-7(2) & 40.6 & 15.2 & 3.1 & -23.3 & 7.2 & - & - & - & - & 16.1 & Early Atlantic \\
\hline OB-14 & 23.3 & 8.3 & 3.3 & -22.6 & 6.4 & - & - & - & - & - & Early Atlantic \\
\hline RCD-6500 & 40.5 & 14.6 & 3.2 & -23.0 & 5.2 & 0.15 & 719 & 222 & 9.7 & 15.9 & Early Atlantic \\
\hline OB-11 & 24.7 & 9.6 & 3.0 & -22.9 & 7.3 & - & - & - & - & - & Boreal/E. Atlantic \\
\hline RAN-9(2) & 36.8 & 13.6 & 3.1 & -22.9 & 7.8 & - & - & - & - & - & Boreal \\
\hline RAN-8(2) & 37.3 & 13.9 & 3.1 & -21.9 & 6.6 & - & - & - & - & - & Boreal \\
\hline BVN-4(2) & 34.9 & 11.7 & 3.5 & -22.7 & 4.9 & 0.15 & 602 & 173 & 6.4 & 16.4 & Boreal \\
\hline BVN-5(2) & 39.2 & 13.9 & 3.3 & -22.4 & 4.7 & - & - & - & - & 16.0 & Boreal \\
\hline BVN-3(2) & 41.4 & 15.2 & 3.2 & -23.2 & 5.8 & 0.15 & 716 & 226 & 5.6 & - & Boreal \\
\hline RCD-6300 & 39.1 & 14.3 & 3.2 & -23.4 & 4.7 & - & - & - & - & 16.8 & Boreal \\
\hline BRT-4 & 40.3 & 14.4 & 3.3 & -22.5 & 4.0 & 0.18 & 603 & 185 & 10.3 & - & Boreal \\
\hline RAN-2 & 44.7 & 15.8 & 3.3 & -23.6 & 7.4 & 0.15 & 818 & 248 & 1.1 & - & Boreal \\
\hline RAN-3 & 41.6 & 15.3 & 3.2 & -23.5 & 8.1 & - & - & - & - & - & Preboreal/Boreal \\
\hline RAN-4 & 43.3 & 14.9 & 3.4 & -23.4 & 7.0 & - & - & - & - & - & Preboreal/Boreal \\
\hline RAN-5 & 42.7 & 15.2 & 3.3 & -24.0 & 7.8 & - & - & - & - & - & Preboreal/Boreal \\
\hline RAN-6 & 44.0 & 14.8 & 3.5 & -22.4 & 6.4 & 0.17 & 681 & 196 & 5.6 & - & Preboreal/Boreal \\
\hline RCD-6200 & 38.8 & 14.2 & 3.2 & -22.5 & 3.5 & 0.19 & 559 & 175 & 7.2 & 16.9 & Preboreal \\
\hline STH-2 & 41.5 & 15 & 3.2 & -22.7 & 3.4 & 0.17 & 667 & 207 & 7.9 & - & Preboreal \\
\hline OB-5 & 42.8 & 15.9 & 3.1 & -21.1 & 4.4 & 0.19 & 601 & 191 & 5.8 & - & Preboreal \\
\hline OB-3 & 20.6 & 7.9 & 3.0 & -21.6 & 2.7 & - & - & - & - & - & Alleröd/Y.Dryas \\
\hline BRT-2 & 40.7 & 15.1 & 3.2 & -19.4 & 3.1 & - & - & - & - & - & Alleröd/Y.Dryas \\
\hline RCD-6400 & 36.8 & 13.4 & 3.2 & -21.5 & 3.8 & - & - & - & - & 15.1 & Alleröd/Y.Dryas \\
\hline RCD-4700 & 39.7 & 14.8 & 3.1 & -19.5 & 1.4 & - & - & - & - & 14.5 & Alleröd/Y.Dryas \\
\hline RCD-4800 & 40.7 & 14.7 & 3.2 & -20.6 & 1.3 & - & - & - & - & 14.9 & Alleröd/Y.Dryas \\
\hline RCD-4900 & 39.9 & 14.8 & 3.2 & -20.0 & 1.3 & 0.14 & 747 & 237 & 3.1 & 14.0 & Alleröd/Y.Dryas \\
\hline RCD-5000 & 39.5 & 14.3 & 3.2 & -20.3 & 0.4 & 0.17 & 629 & 195 & 2.7 & 14.4 & Alleröd/Y.Dryas \\
\hline RCD-5100 & 39.8 & 14.7 & 3.2 & -20.0 & 0.2 & 0.18 & 593 & 187 & 8.5 & 14.1 & Alleröd/Y.Dryas \\
\hline OB-1 & 39.3 & 13.7 & 3.4 & -20.1 & 2.7 & - & - & - & - & - & Alleröd \\
\hline BRT-1 & 42.1 & 14.5 & 3.4 & -20.9 & 1.4 & - & - & - & - & - & Alleröd \\
\hline BRT-3 & 38.6 & 14.1 & 3.2 & -20.6 & 1.0 & 0.13 & 763 & 239 & 0.4 & - & Alleröd \\
\hline RCD-2300 & 38.5 & 14.2 & 3.2 & -20.8 & 1.6 & 0.15 & 673 & 212 & 4.0 & 14.9 & Alleröd \\
\hline RCD-2400 & 38.9 & 13.3 & 3.2 & -20.6 & 3.1 & 0.18 & 575 & 169 & 1.7 & 14.8 & Alleröd \\
\hline RCD-2500 & 40.0 & 14.6 & 3.2 & -21.2 & 2.6 & - & - & - & - & 14.6 & Alleröd \\
\hline RCD-2600 & 38.8 & 14.0 & 3.2 & -20.0 & 2.3 & 0.16 & 656 & 204 & 3.3 & 15.1 & Alleröd \\
\hline RCD-2700 & 38.2 & 14.2 & 3.2 & -20.9 & 1.6 & 0.16 & 653 & 207 & 1.4 & 15.4 & Alleröd \\
\hline RCD-2800 & 40.3 & 14.7 & 3.2 & -20.5 & 1.3 & 0.14 & 771 & 241 & -0.1 & 14.8 & Alleröd \\
\hline RCD-900 & 40.3 & 14.6 & 3.2 & -20.1 & 1.8 & - & - & - & - & 15.0 & Alleröd \\
\hline RCD-1000 & 42.5 & 15.4 & 3.2 & -20.7 & 2.5 & - & - & - & - & 15.1 & Alleröd \\
\hline RCD-1100 & 42.0 & 15.3 & 3.2 & -21.9 & 3.0 & 0.15 & 728 & 228 & 4.2 & 15.3 & Alleröd \\
\hline RCD-1200 & 38.9 & 14.4 & 3.1 & -19.9 & 1.3 & - & - & - & - & 14.8 & Alleröd \\
\hline RCD-1300 & 37.8 & 13.9 & 3.2 & -20.6 & 2.0 & - & - & - & - & 14.8 & Alleröd \\
\hline RCD-1400 & 41.0 & 15.0 & 3.2 & -20.7 & 0.4 & - & - & - & - & 14.9 & Alleröd \\
\hline BVN-9(2) & 28.1 & 10.3 & 3.2 & -20.8 & 2.1 & - & - & - & - & 15.3 & Bölling/Alleröd \\
\hline RCD-500 & 42.3 & 15.5 & 3.2 & -19.9 & 0.8 & - & - & - & - & 15.0 & Bölling/Alleröd \\
\hline RCD-600 & 41.2 & 14.8 & 3.2 & -20.1 & - & 0.15 & 744 & 229 & 1.8 & 14.9 & Bölling/Alleröd \\
\hline RCD-10900 & 41.7 & 16.0 & 3.0 & -20.4 & 2.0 & - & - & - & - & - & Bölling/Alleröd \\
\hline RCD-11000 & 44.0 & 16.1 & 3.2 & -20.6 & 2.4 & - & - & - & - & - & Bölling/Alleröd \\
\hline
\end{tabular}

forest (De Beaulieu et al., 1994). Moreover, increase in temperature favors plant biomass decomposition, organic nitrogen mineralization and loss of soil nitrate by volatilization (Sprent, 1987; Garten, 1993), all those processes driving to higher $\delta^{15} \mathrm{~N}$ values in plants from boreal and peri-arctic ecosystems (Nadelhoffer and Fry, 1994; Amundson et al., 2003). During the Late-glacial, soils in Jura and the
Alps were recently released from the influence of the local glaciers. The persistence of low temperature, low biomass and low soil $\mathrm{N}$ content could explain the relatively low $\delta^{15} \mathrm{~N}_{\text {coll }}$ of red deer with no distinction between the two regions $(0.2-3.8 \%$ in Jura, $1.3-3.6 \%$ in the Alps; Tables 2 and 3, Fig. 5). Based on the same mechanisms, the gradient of decreasing $\delta^{15} \mathrm{~N}$ values of soils and plants and their 
Table 3

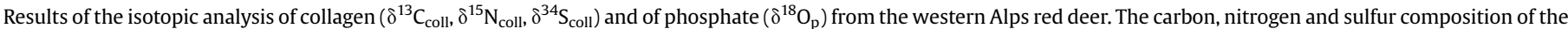

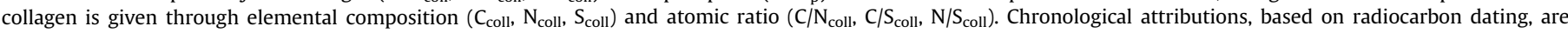
indicated using pollen chronozone.

\begin{tabular}{|c|c|c|c|c|c|c|c|c|c|c|c|}
\hline Lab $n^{\circ}$ & $\mathrm{C}_{\text {coll }}(\%)$ & $\mathrm{N}_{\text {coll }}(\%)$ & $\mathrm{C} / \mathrm{N}_{\text {coll }}$ & $\delta^{13} C_{\text {coll }}(\%)$ & $\delta^{15} \mathrm{~N}_{\text {coll }}(\%)$ & $\mathrm{S}_{\text {coll }}(\%)$ & $\mathrm{C} / \mathrm{S}_{\text {coll }}(\%)$ & $\mathrm{N} / \mathrm{S}_{\text {coll }}(\%)$ & $\delta^{34} S_{\text {coll }}(\%)$ & $\delta^{18} \mathrm{O}_{\mathrm{p}}(\%)$ & Pollen chronozone \\
\hline LUS-2 & 41.7 & 15.2 & 3.2 & -18.7 & 2.2 & 0.12 & 908 & 283 & 6.4 & - & Early Atlantic \\
\hline APS-2 & 42.9 & 15.9 & 3.2 & -21.7 & 4.2 & - & - & - & - & - & Early Atlantic \\
\hline GRV-12 & 39.9 & 14.7 & 3.2 & -20.9 & 4.0 & - & - & - & - & 12.7 & Early Atlantic \\
\hline GRV-9 & 41.8 & 15.6 & 3.1 & -21.1 & 3.6 & 0.16 & 692 & 221 & 3.9 & 15.1 & Early Atlantic \\
\hline GRV-5 & 41.4 & 15.1 & 3.2 & -21.1 & 3.2 & 0.12 & 935 & 292 & 6.4 & 14.7 & Boreal \\
\hline FRU-2 & 35.2 & 13.7 & 3.0 & -22.4 & 4.2 & 0.15 & 620 & 207 & 6.0 & 15.7 & Boreal \\
\hline FRU-9 & 39.4 & 14.8 & 3.1 & -20.2 & 1.6 & 0.15 & 693 & 223 & 2.3 & - & Boreal \\
\hline GRV-1 & 42.1 & 15.3 & 3.2 & -20.4 & 2.2 & 0.15 & 749 & 234 & 6.4 & - & Preboreal \\
\hline FRU-3 & 32.7 & 12.4 & 3.1 & -21.1 & 2.7 & - & - & - & - & - & Preboreal \\
\hline FRU-1 & 38.1 & 13.7 & 3.2 & -20.1 & 2.4 & - & - & - & - & - & Preboreal \\
\hline FRU-6 & 36.8 & 13.9 & 3.1 & -20.2 & 1.8 & 0.15 & 635 & 206 & 3.0 & - & Y. Dryas \\
\hline FRU-7 & 34.5 & 13.2 & 3.1 & -20.3 & 1.6 & 0.17 & 530 & 174 & 3.5 & - & Y. Dryas \\
\hline FRU-4 & 29.5 & 11.6 & 3.0 & -20.8 & 3.1 & 0.12 & 676 & 228 & 5.5 & 16.7 & Alleröd \\
\hline FRU-13 & 43.3 & 16.0 & 3.2 & -20.2 & 3.0 & 0.15 & 772 & 245 & 6.6 & 15.9 & Alleröd \\
\hline FRU-15 & 42.7 & 15.9 & 3.1 & -21.1 & 3.3 & 0.17 & 689 & 219 & 5.9 & - & Alleröd \\
\hline FRU-10 & 43.7 & 16.0 & 3.2 & -19.9 & 2.2 & 0.15 & 765 & 239 & 3.4 & - & Alleröd \\
\hline LDT-200 & 41.7 & 15.3 & 3.2 & -20.7 & - & - & - & - & - & - & Bölling/Alleröd \\
\hline FRU-11 & 41.5 & 15.7 & 3.1 & -19.2 & 1.3 & 0.16 & 698 & 227 & 2.6 & - & Bölling/Alleröd \\
\hline FRU-5 & 36.3 & 14.1 & 3.0 & -20.3 & 3.6 & 0.16 & 614 & 205 & -0.2 & 18.3 & Bölling \\
\hline LDT-600 & 41.8 & 15.4 & 3.2 & -19.8 & 2.0 & 0.14 & 786 & 249 & -3.1 & - & O. Dryas/Bölling \\
\hline
\end{tabular}

consumers is found with increasing altitude (e.g. Männel et al., 2007). It could explain the lower red deer $\delta^{15} \mathrm{~N}_{\text {coll }}$ found in the Alps than in Jura during the early Holocene (Man$\mathrm{n}$-Whitney-Wilcoxon test, $p<0.0001$ ). However, the lack of significant $\delta^{15} \mathrm{~N}_{\text {coll }}$ increase in the Alps red deer over the Late-glacial to early Holocene transition was rather unexpected. Occurrence of oak mixed forest was documented as high as $1500 \mathrm{~m}$ asl during the Boreal in the Alps. Thus, the development of soil maturity in the Alps should be reflected by an increase in the $\delta^{15} \mathrm{~N}$ values of soils and thus on plants consumed by red deer. The stability of the red deer $\delta^{15} \mathrm{~N}_{\text {coll }}$ values in the Alps through the considered period as well as the lack of significant canopy effect could be linked to a change in home range toward higher altitude areas in the early Holocene.

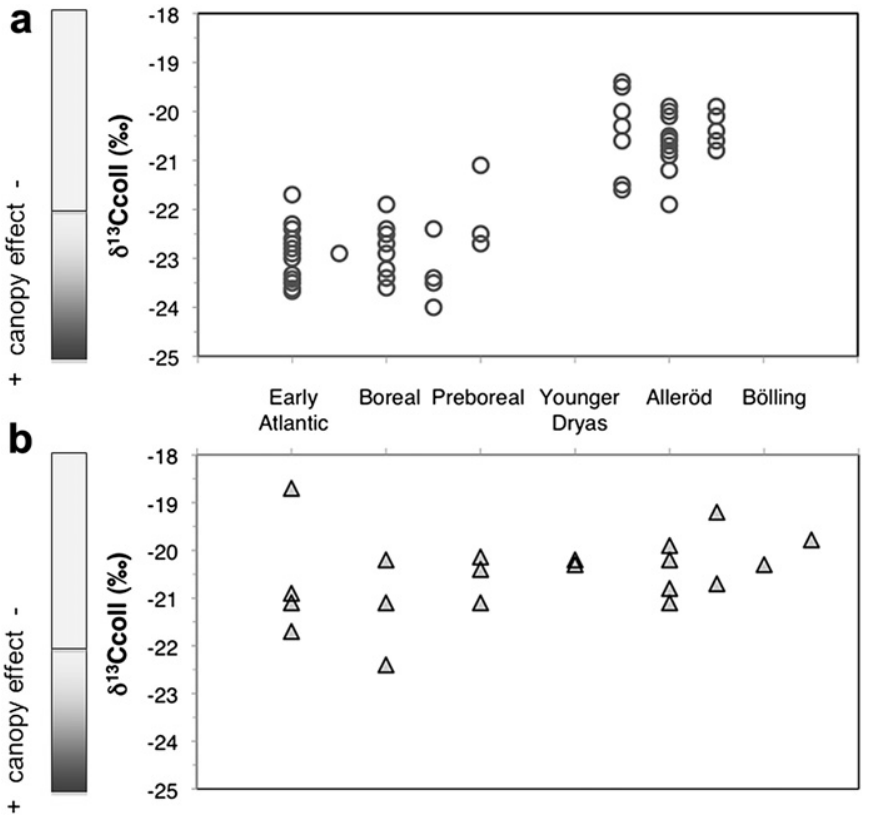

Fig. 3. The $\delta^{13} \mathrm{C}_{\text {coll }}$ values of directly and un-directly red deer (Cervus elaphus) from the French Jura in a) and the western Alps in b). Values below ca. $-22 \%$ are interpreted as the result of the canopy effect. Chronological attributions are given in Table S1 and S2.

\subsection{Oxygen-18 and altitude}

The increase in red deer $\delta^{18} \mathrm{O}_{\mathrm{p}}$ values observed in the French Jura site of Rochedane at the Late-glacial/early Holocene transition (Drucker et al., 2009) was confirmed by the new data obtained in the nearby site of Bavans (Table 2). The linear relationship between the $\delta^{15} \mathrm{~N}_{\text {coll }}$ values and $\delta^{18} \mathrm{O}_{\mathrm{p}}$ values measured on the same specimens was also confirmed but with a coefficient of correlation slightly lower $\left(r^{2}=0.60\right)$ than the one calculated for the sole site of Rochedane $\left(r^{2}=0.67\right)$ (Fig. 6). Local effect in terms of hydrogeology could influence the general pattern of global warming resulting in global increase in $\delta^{18} \mathrm{O}$ values of available drinking water.

The isotopic contrast between Jura and Alps red deer was also reflected in $\delta^{18} \mathrm{O}_{\mathrm{p}}$ values of red deer despite more limited number of data (Tables 2 and 3, Fig. 7). While higher $\delta^{18} \mathrm{O}_{\mathrm{p}}$ values were measured in the Alps (La Grande Rivoire and La Fru sites) than in Jura during the Late-glacial, a reverse pattern was observed during the early Holocene. Difference in Late-glacial $\delta^{18} \mathrm{O}_{\mathrm{p}}$ values between both regions may be explained by higher aridity rather than higher temperature in the Alps compared to French Jura. In the early

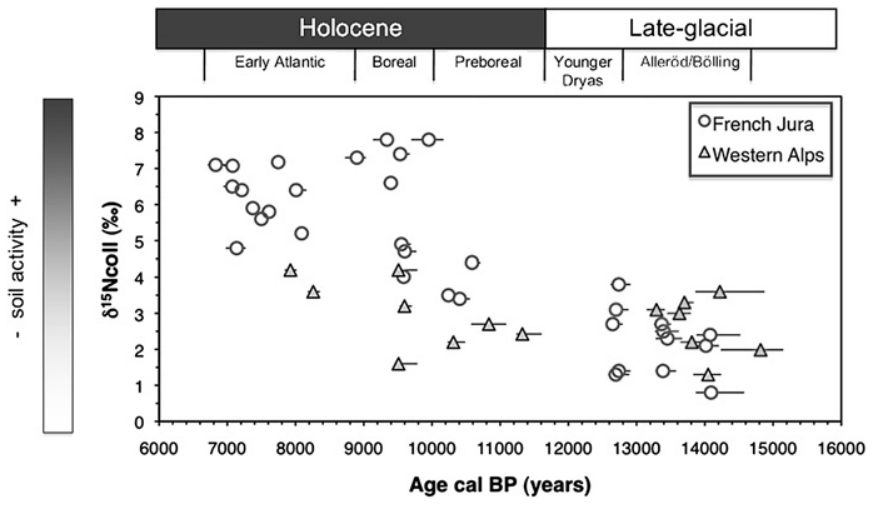

Fig. 4. The $\delta^{15} \mathrm{~N}_{\text {coll }}$ values of AMS dated red deer (Cervus elaphus) from the French Jura (white circles) and the western Alps (grey triangles) against time through the Lateglacial to early Holocene transition. Increasing collagen $\delta^{15} \mathrm{~N}$ values are interpreted as the result of increasing soil activity. The AMS results were calibrated at based on intcal09.14C calibration dataset and calculated by CALIB REV6.0.0 program (Reimer et al., 2009). 

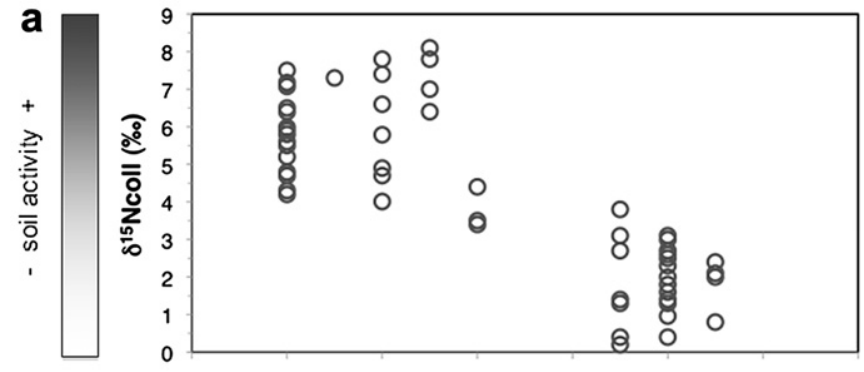

b
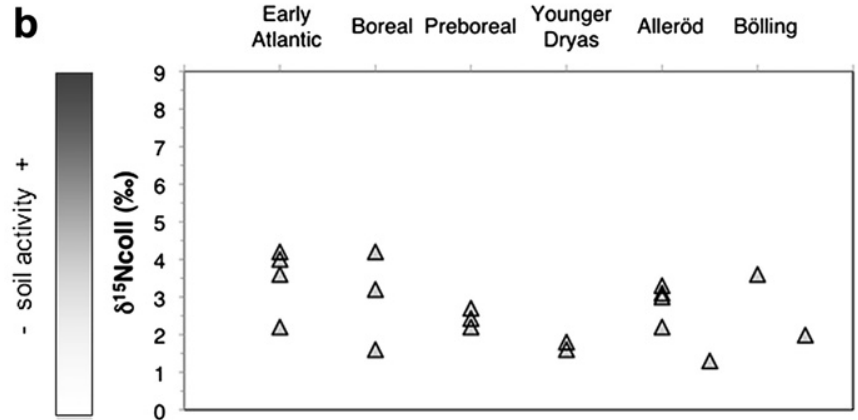

Fig. 5. The $\delta^{15} \mathrm{~N}_{\text {coll }}$ values of directly and un-directly red deer (Cervus elaphus) from the French Jura in a) and the western Alps in b). Increasing collagen $\delta^{15} \mathrm{~N}$ values are interpreted as the result of increasing soil activity. Chronological attributions are given in Table S1 and S2.

Holocene, the low $\delta^{18} \mathrm{O}_{\mathrm{p}}$ values of the Alps red deer could correspond to local temperatures lower than in Jura. However, the $\delta^{18} \mathrm{O}_{\mathrm{p}}$ values of red deer from the Alps were not only lower to those of the red deer from Jura, but also from those of the red deer of the same sites in the previous period of the Late-Glacial. A decrease of $\delta^{18} \mathrm{O}_{\mathrm{p}}$ values at the Late-glacial to early Holocene transition could be attributed to the driving effect of increasing humidity instead of the impact of increasing temperature observed in Jura. However, the combined action of lower aridity and higher temperature should have led to higher $\delta^{15} \mathrm{~N}$ values of plants and their consumers over time, while no change in ${ }^{15} \mathrm{~N}$ abundances of red deer collagen was observed in the Alps. Similarly, the increase in water availability

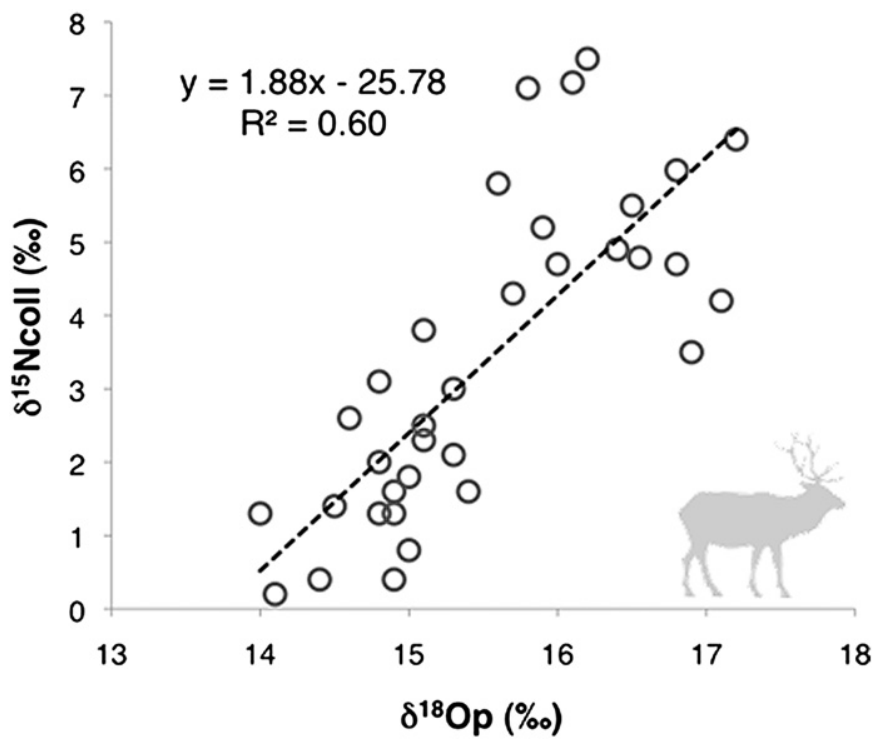

Fig. 6. Relationship between the $\delta^{15} \mathrm{~N}_{\text {coll }}$ values and the $\delta^{18} \mathrm{O}_{\mathrm{p}}$ values measured on the same bone of red deer (Cervus elaphus) from Rochedane and Bavans in French Jura. A positive linear correlation is found that confirms the indirect influence of climate on the ${ }^{15} \mathrm{~N}$ amounts in red deer collagen at the Late-glacial to early Holocene transition.

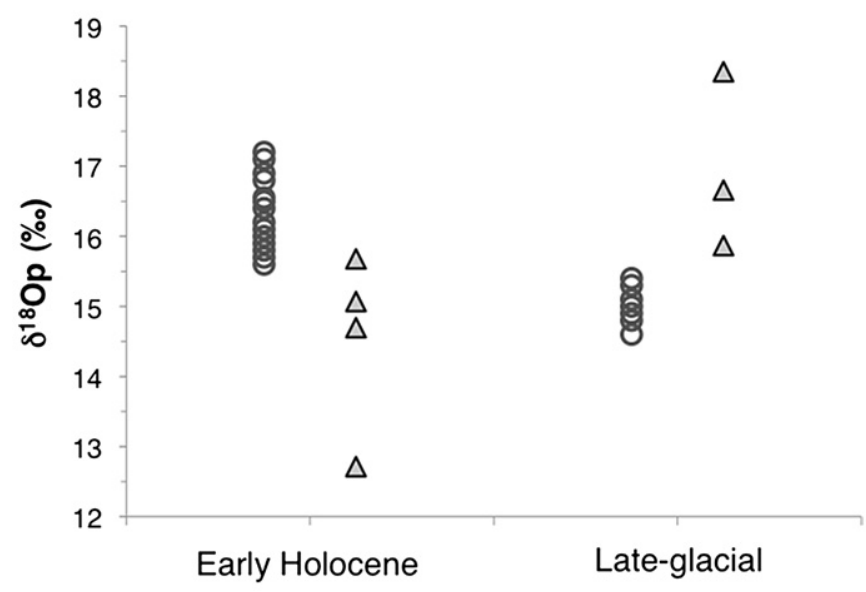

Fig. 7. The $\delta^{18} \mathrm{O}_{\mathrm{p}}$ values of red deer (Cervus elaphus) from the French Jura (white circles, sites of Rochedane and Bavans) and the western Alps (grey triangles, sites of La Grande Rivoire and La Fru) at the Late-glacial and early Holocene periods. The increase in red deer $\delta^{18} \mathrm{O}_{\mathrm{p}}$ values in the French Jura over time is considered to be the result of the global rise of temperature. In contrast, the decreasing in red deer $\delta^{18} \mathrm{O}_{\mathrm{p}}$ values in western Alps is interpreted as a change in habitat toward areas higher in altitude in the early Holocene compared to the Late-glacial.

was expected to enhance the decrease in $\delta^{13} \mathrm{C}$ of forage linked to the canopy effect, whereas only a slight decrease in $\delta^{13} C_{\text {coll }}$ values of red deer could be suspected in the western Alps. Thus, higher altitude in the home range of the Alps red deer, due to an altitudinal movement of the animals and/or a change in human hunting territories, could explain the trends provided together by the $\delta^{13} \mathrm{C}_{\text {coll }}, \delta^{15} \mathrm{~N}_{\text {coll }}$ and $\delta^{18} \mathrm{O}_{\mathrm{p}}$ values in the early Holocene compared to the Late-glacial.

\subsection{Sulphur-34, soil warming and mobility}

The $\delta^{34} \mathrm{~S}_{\text {coll }}$ values measured on the red deer from Jura ranged between -0.1 and $8.5 \%$ for the Late-Glacial period and 1.1 and $10.3 \%$ for the early Holocene period (Table 2, Fig. 8). The collagen ${ }^{34} \mathrm{~S}$ abundances of Jura red deer were thus significantly more positive in the Holocene than in the Late-glacial (Mann-Whitney-Wilcoxon test, $p<0.001)$. In the western Alps (Table 3, Fig. 8), the red deer $\delta^{34} \mathrm{~S}_{\text {coll }}$ values varied from $-3.1-6.6 \%$ with no significant contrast between the Late-glacial $(-3.1-6.6 \%)$ and the early Holocene $(2.3-6.4 \%$ o $)$. There was also no significant difference in ${ }^{34} \mathrm{~S}$ abundances between French Jura and the western Alps during the Late-glacial despite the rather low $\delta^{34} \mathrm{~S}_{\text {coll }}$ value exhibited by LDT-600 specimen $(-3.1 \%$ o from the Alps. In the early Holocene, the red deer from Jura had significantly higher $\delta^{34} \mathrm{~S}_{\text {coll }}$ values than those of red deer from the Alps (Man$\mathrm{n}$-Whitney-Wilcoxon test, $p<0.05)$. Thus, the pattern of $\delta^{34} \mathrm{~S}_{\text {coll }}$ variation over time in a given region or between regions in a given period was comparable to the pattern of $\delta^{15} \mathrm{~N}_{\text {coll }}$ variation. A part of the sulphur assimilated by plants derives from soil sources (Peterson and Fry, 1987). Interestingly, both $\delta^{15} \mathrm{~N}$ and $\delta^{34} \mathrm{~S}$ values in soil profiles show increase with depth, and similar behavior of $\mathrm{N}$ and $\mathrm{S}$ stable isotopes are found in soils like the preferential assimilation of lighter isotopes $\left({ }^{14} \mathrm{~N},{ }^{32} \mathrm{~S}\right)$ and the enrichment in heavier isotopes ${ }^{15} \mathrm{~N}$ and ${ }^{34} \mathrm{~S}$ of the in situ residues of mineralization (Novák et al., 2003). Moreover, volatilization processes favor the lighter isotopes and result in the enrichment of heaver isotopes in the remaining soil residues (Fry et al., 1986; Högberg, 1997).

The impact of the Late-glacial to early Holocene global warming through soil processes could be suspected for the evolution of red deer $\delta^{34} S_{\text {coll }}$ values over time in Jura as it was hypothesized for the 

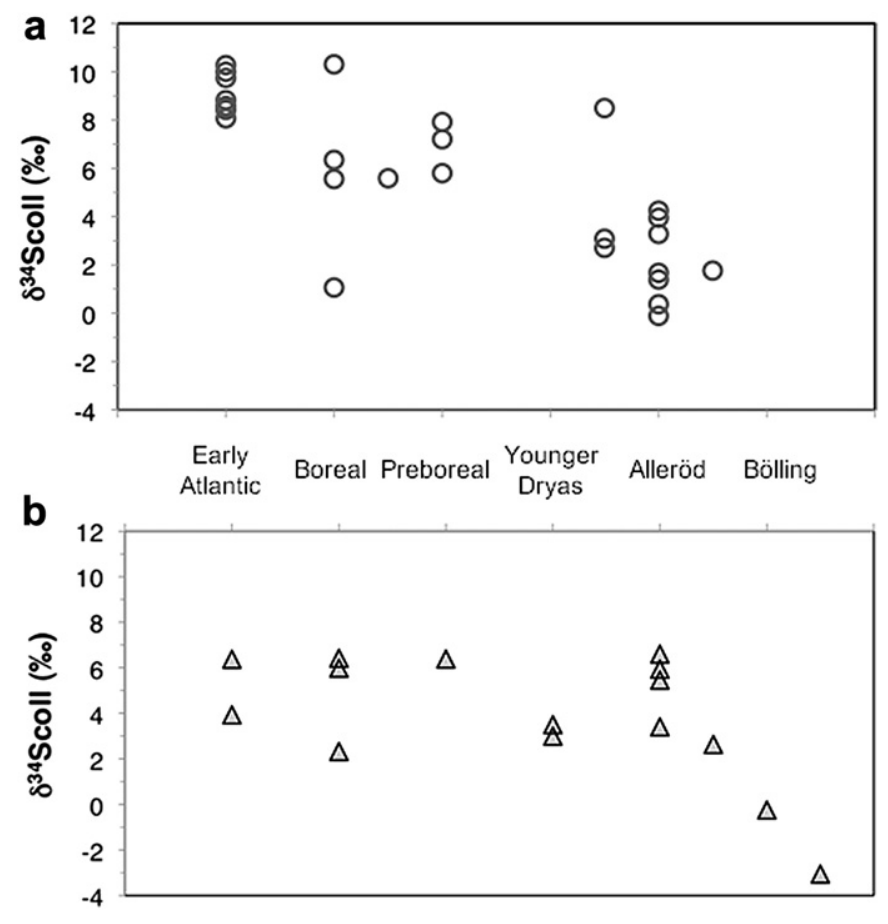

Fig. 8. The $\delta^{34} S_{\text {coll }}$ values of directly and un-directly red deer (Cervus elaphus) from the French Jura in a) and the western Alps in b). Difference in collagen $\delta^{34} S$ values for a given chronozone is thought to result from contrast in nature of geological bedrock. Chronological attributions are given in Table S1 and S2.

coeval $\delta^{15} \mathrm{~N}_{\text {coll }}$ values. Increasing temperatures could lead to an increase in the $\delta^{34} \mathrm{~S}$ values of soils by increasing the rate of mineralization and volatilization of sulphur (Fry et al., 1986; Novák et al., 2003). Moreover, higher temperatures lead to higher rate of bacterial reduction (Kaplan and Rittenberg, 1964), which results in less ${ }^{34} \mathrm{~S}$ depletion in the reduced products (Krouse and Mayer, 2000). It would thus be possible that the $\delta^{34} S_{\text {coll }}$ values of red deer reflected the increasing soil activity linked to increasing temperature at the Late-glacial/early Holocene transition in Jura. Local effect could be hypothesized for RAN-2 specimens that had a relatively low $\delta^{34} \mathrm{~S}$ value $(1.1 \%$ ) compared to the other Holocene red deer form Jura (5.6-10.3\%) as well as for the RCD-5100 specimen that gave a rather high $\delta^{34} \mathrm{~S}_{\text {coll }}$ value $(8.5 \%)$ compared to the other Late-Glacial red deer from Jura $(-0.1-4.2 \%)$. RAN-2 provided one of the highest $\delta^{15} \mathrm{~N}_{\text {coll }}$ values of the Boreal chronozone while RCD-5100 had the lowest $\delta^{15} \mathrm{~N}_{\text {coll }}$ value of the Late-glacial period. This is not consistent with the observed rough correlation between $\delta^{34} \mathrm{~S}_{\text {coll }}$ and $\delta^{15} \mathrm{~N}_{\text {coll }}$ values over time. The studied sites of Jura are situated on soils dominated by limestones with some areas of detrital deposit and some granitic massifs such as the massif of La Serre close to Ranchot and the Vosges close to Oberlarg. Thus, some differences in the nature of the geological bedrock could explain the cause of local soil $\delta^{34} \mathrm{~S}$ values contrast reflected by some red deer specimens. A more systematic survey of $\delta^{34} \mathrm{~S}$ values of different bedrocks found in Jura could provide the baseline to investigate mobility during the Late-glacial and the Holocene in this region.

\section{Conclusions}

The analysis of different stable isotopes on red deer collagen offered the possibility to track combined local conditions of habitat using ${ }^{13} \mathrm{C}$, climate using ${ }^{18} \mathrm{O}$, and soil using ${ }^{15} \mathrm{~N}$. Results in ${ }^{34} \mathrm{~S}$ confirmed the potential of this isotope to reflect the mobility of mammals in purely terrestrial contexts. The multi-element stable isotope analysis of red deer from eastern France at the Late-glacial/ early Holocene transition evidenced temporal and geographical contrasts linked to differences in the response of red deer populations facing a significant change in their environment. A drastic modification in ethology was reflected by the red deer of French Jura with the change of habitat to dense forest in warmer and more productive conditions. In contrast, the red deer of the western Alps persisted in open landscape and rather cool conditions with low soil productivity by dwelling at higher altitudes than before. This difference in adaptation to the global warming of the early Holocene was probably favored by the difference in topography between the two regions. It is also interesting to note that a species such as red deer, traditionally associated with forested environments, even if it is sufficiently flexible to cope with more open landscapes, continued to favor open environments, even when closed-canopy environments were available in the surrounding areas.

As the studied specimens come from archaeological sites, selection by prehistoric human hunters should also be considered. For example, the occurrence of red deer groups in dense forest at low altitude in the Alps cannot be excluded, as human populations may have preferred to hunt red deer in open areas for technical and/or cultural reasons. If it were the case, the isotopic results obtained on red deer would also give an insight on human foraging of their environment. In any case, the multi-element stable isotope tracking of red deer is a valuable tool to decipher the ecological response of a terrestrial ungulate to changing environment.

\section{Acknowledgements}

This research was supported by the CNRS through a PEVS project (coord. Hervé Bocherens, PL97-42) and an Eclipse project (coord. Anne Bridault, $n^{\circ}$ 0693), and by the Ministry of Culture and regional funding through two PCR projects (coord., Gilbert Pion, P08 from 1997 to 2002: "La fin du Paléolithique supérieur dans les Alpes du nord françaises et le Jura méridional; coord. Christophe Cupillard $n^{\circ}$ 06/073 from 2005 to 2008: "Le Tardiglaciaire et le début de l'Holocène dans le massif du Jura et ses marges). Sample preparation and isotopic measurements were conducted with the technical assistance of Françoise Sainteny (ArScAn-UMR7041, Nanterre), Andrea Orendi, Bernd Steinhilber and Christoph Wissing (Department of Geoscience, University of Tübingen). We are also grateful to Cyril Bernard and Pierre Bintz for provinding the map outline (AVDPRA, Grenoble).

\section{Appendix. Supplementary data}

Supplementary data associated with this article can be found, in the online version, at doi:10.1016/j.quaint.2011.07.015.

\section{References}

Aimé, G., 1993. Les abris-sous-roche de Bavans (Doubs). Archéologie 3. Mémoires de la SALSA, Vesoul.

Ambrose, S.H., 1990. Preparation and characterization of bone and tooth collagen for isotopic analysis. Journal of Archaeological Science 17, 431-451.

Amman, B., Lotter, A.F., 1989. Late-Glacial radiocarbon- and palynostratigraphy on the Swiss Plateau. Boreas 18, 109-126.

Amundson, R., Austin, A.T., Scuur, E.A.G., Yoo, K., Matzek, V., Kendall, C., Uerbersax, A., Brenner, D., Baisden, W.T., 2003. Global patterns of the isotopic composition of soil and plant nitrogen. Global Biogeochemical Cycles 17 (1), 1031.

Arens, N.C., Jahren, A.H., Amundson, R., 2000. Can $C_{3}$ plants faithfully record the carbon isotopic composition of atmospheric carbon dioxide? Paleobiology 26 (1), 137-164.

Balasse, M., Bocherens, H., Ambrose, S.H., Mariotti, A., 2001. Detection of dietary changes by intra-tooth carbon and nitrogen isotopic analysis: an experimental 
study of dentine collagen of cattle (Bos taurus). Journal of Archaeological Science 28, 235-245.

Barboza, P.S., Parker, K.L., 2006. Body protein stores and isotopic of $\mathrm{N}$ balance in female reindeer (Rangifer tarandus) during winter. Physiological and Biochemical Zoology 79, 628-644.

Barnett, B.A., 1994. Carbon and nitrogen ratios of caribou tissues, vascular plants and lichens from Northern Alaska. M.Sc. thesis, The University of Alaska Fairbanks, A.K.

Bintz, P., Pelletier, D., 2000. Le site d'altitude du Mésolithique et du Néolithique de L'Aulp-du-Seuil (Saint-Bernard-du-Touvet, Isère, France). Premiers résultats. In: Crotti, P. (Ed.), Epipaléolithique et Mésolithique. Actes de la table-ronde de Lausanne. Cahiers d'Archéologie Romande 81, Lausanne, Switzerland, pp. 189-195.

Björck, S., Walker, MJ.C. Cwynar, L.C. Johnsen, S., Knudsen, K.-L, Lowe, JJ. Wohlfarth, B., INTIMATE members, 1998. An event stratigraphy for the last termination in the North Atlantic region based on the Greenland ice-core record: a proposal by the INTIMATE group. Journal of Quaternary Science 13, $283-292$.

Bocherens, H., Koch, P.L., Mariotti, A., Geraads, D., Jaeger, J.-J., 1996. Isotopic biogeochemistry $\left({ }^{13} \mathrm{C},{ }^{18} \mathrm{O}\right)$ of mammal enamel from African Pleistocene hominid sites: implications for the preservation of paleoclimatic isotopic signals. Palaios 11, 306-318.

Bocherens, H., Billiou, D., Patou-Mathis, P., Bonjean, D., Otte, M., Mariotti, A., 1997. Paleobiological implications of the isotopic signature $\left({ }^{13} \mathrm{C},{ }^{15} \mathrm{~N}\right)$ of fossil mammal collagen in Scladina cave (Sclayn, Belgium). Quaternary Research 48 $370-380$.

Bridault, A., Chaix, L., Pion, G., Oberlin, C., Thiébault, S., Argant, J., 2000. Position chronologique du renne (Rangifer tarandus L.) à la fin du Tardiglaciaire dans les Alpes du Nord françaises et le Jura méridional. Mémoire de la Société de Préhistoire française 28, 47-57.

Britton, K.H., 2009. Multi-isotope analysis and the reconstruction of prey species palaeomigrations and palaeoecology. Doctoral thesis, Durham University, http://etheses.dur.ac.uk/216/.

Broadmeadow, M.S.J., Griffiths, H., Maxwell, C., Borland, A.M., 1992. The carbon isotope ratio of plant organic material reflects temporal and spatial variations in $\mathrm{CO}_{2}$ within tropical forest formations in Trinidad. Oecologia 89, 435-441.

Camin, F., Bontempo, L., Heinrich, K., Horacek, M., Kelly, S.D., Schlicht, C., Thomas, F. Monahan, F.J., Hoogewerff, J., Rossmann, A., 2007. Multi-element (H, C, N, S) stable isotope characteristics of lamb meat from different European regions. Analytical and Bioanalytical Chemistry 389, 309-320.

Campy, M., Chaline, J., Vuillemey, M., 1989. La Baume de Gigny (Jura). Editions du CNRS, Paris.

Chaffenet, G., Cordier, F., 1999. L'abri des Corréardes à Lus-la-Croix-Haute (Drôme): un site de chasse du Néolithique ancien dans la haute vallée du Buëch. Trav. Du Centre d'archéol. préhist. de Valence ; 2, Programme collectif de rech. CIRCALP 1997-1998. In: Beeching, A. (Ed.), Circulations et identités culturelles alpines à la fin de la préhistoire: matériaux pour une étude. Valence: Centre d'archéol. préhist, pp. 359-371.

Craig, O.E., Ross, R., Andersen, S.H., Milner, N., Bailey, G.N., 2006. Focus: Sulphur isotope variation in archaeological marine fauna from northern Europe. Journal of Archaeological Science 33, 1642-1646.

Craig, O.E., Biazzo, M., Colones, A.C., Di Giuseppe, Z., Martinez-Labarga, C., Lo Vetro, D., Lelli, R., Martini, F., Rickards, O., 2010. Stable isotope analysis of Late Upper Palaeolithic human and faunal remains from Grotta del Romito (Cosenza), Italy. Journal of Archaeological Science 37, 2504-2512.

Cupillard, C., 2008. Le Tardiglaciaire et le début de l'Holocène dans le massif du Jura et ses marges. $20000-5000$ avant J.-C.: des derniers chasseurs de rennes aux premiers agriculteurs. Projet Collectif de Recherche (PCR), 2005-2008. Rapport 2008, Besançon: SRA de Franche-Comté et Laboratoire de Chronoenvironnement, UMR 6249 du CNRS, France.

Cupillard, C., David, S., 1995. La prédation au Magdalénien final et au Mésolithique: les chasseurs-cueilleurs de l'abri des Cabônes à Ranchot (Jura). In: Richard, A Munier, C. (Eds.), Eclats d'histoire, 25000 ans d'héritages, 10 ans d'archéologie en Franche-Comté. Cêtre, Besançon, pp. 104-109.

Cupillard, C., Chaix, L., Piningre, J.-F., Bourgeois, D., 2000. Les occupations mésolithiques de la grotte de la Baume de Montandon à Saint-Hippolyte (Doubs, France). In: Richard, A., Cupillard, C., Richard, H., Thévenin, A. (Eds.), Les derniers chasseurs-cueilleurs d'Europe occidentale (13000-5500 avant J.-C.). Actes du Colloque international de Besançon (Doubs, France). Presses Universitaires Franc-Comtoises, Collection Annales Littéraires, Besançon, pp. 219-251.

D’Angela, D., Longinelli, A., 1990. Oxygen isotopes in living mammal's bone phosphate: further results. Chemical Geology (Isotope Geoscience Section) 86 $75-82$

Dawson, T.E., Mambelli, S., Plamboeck, A.H., Templer, P.H., Tu, K.P., 2002. Stable isotopes in plant ecology. Annual review of ecology. Evolution and Systematics 33, 507-559.

De Beaulieu, J.-L., Richard, H., Ruffaldi, P., Clerc, J., 1994. History of vegetation, climate and human action in the French Alps and the Jura over the last 15,000 years. Dissertationes Botanicœ 234, 253-275.

DeNiro, M.J., 1985. Postmortem preservation and alteration of in vivo bone collagen isotope ratios in relation to palaeodietary reconstruction. Nature 317, 806-809.

Diefendorf, A.F., Mueller, K.E., Wing, S.L., Koch, P.L., Freeman, K.H., 2010. Global patterns in leaf ${ }^{13} \mathrm{C}$ discrimination and implications for studies of past and future climate. Proceedings of the National Academy of Science 107, 5738-5743.

Drucker, D., Bocherens, H., Billiou, D., 2003a. Evidence for shifting environmental conditions in Southwestern France from 33,000 to 15,000 years ago derived from carbon-13 and nitrogen-15 natural abundances in collagen of large herbivores. Earth and Planetary Science Letters 216, 163-173.

Drucker, D., Bocherens, H., Bridault, A., Billiou, D., 2003b. Carbon and nitrogen isotopic composition of red deer (Cervus elaphus) collagen as a tool for tracking palaeoenvironmental change during the Late-Glacial and Early Holocene in the northern Jura (France). Palaeogeography, Palaeoclimatology, Palaeoecology 195, 375-388.

Drucker, D.G., Bridault, A., Hobson, K.A., Szuma, E., Bocherens, H., 2008. Can collagen carbon-13 abundance of large herbivores reflect the canopy effect in temperate and boreal ecosystems? Evidence from modern and ancient ungulates. Palaeogeography, Palaeoclimatology, Palaeoecology 266, 69-82.

Drucker, D.G., Bridault, A., Iacumin, P., Bocherens, H., 2009. Bone stable isotopic signatures $\left({ }^{15} \mathrm{~N},{ }^{18} \mathrm{O}\right)$ as tracers of temperature variation during the Late-glacial and early Holocene: a case study on red deer Cervus elaphus from Rochedane (Jura, France). Geological Journal 44, 593-604.

Drucker, D.G., Hobson, K.A., Ouellet, J.-P., Courtois, R., 2010. Influence of forage preferences and habitat use on ${ }^{13} \mathrm{C}$ and ${ }^{15} \mathrm{~N}$ abundance in wild caribou (Rangifer tarandus caribou) and moose (Alces alces) from Canada. Isotopes in Environmental and Health Studies 46 (1), 107-121.

Drucker, D.G., Hobson, K.A., Münzel, S.C., Pike-Tay, A. in press. Intra-individual variation in stable carbon $\left(\delta^{13} \mathrm{C}\right)$ and nitrogen $\left(\delta^{15} \mathrm{~N}\right)$ isotopes in mandibles of modern caribou of Qamanirjuaq (Rangifer tarandus groenlandicus) and Banks Island (Rangifer tarandus pearyi): implications for tracing seasonal and temporal changes in diet. International Journal of Osteoarchaeology, doi: 10.1002/ oa. 1220 .

Farquhar, G.D., Ehleringer, J.R., Hubick, K.T., 1989. Carbon isotope discrimination and photosynthesis. Annual Review of Plant Physiology and Plant Molecular Biology 40, 503-537.

Fricke, H.C., O'Neil, J.R., 1999. The correlation between ${ }^{18} \mathrm{O} /{ }^{16} \mathrm{O}$ ratios of meteoric water and surface temperature: its use in investigating terrestrial climate change over geologic time. Earth and Planetary Science Letters 170, 181-196.

Fricke, H.C., Clyde, W.C., O'Neil, J.R., 1998. Intra-tooth variations in $\delta^{18} \mathrm{O}\left(\mathrm{PO}_{4}\right)$ of mammalian tooth enamel as a record of seasonal variations in continental climate variables. Geochemica et Cosmochimica Acta 6, 1839-1850.

Fry, B., Gest, H., Hayes, J.M., 1986. Sulfur isotope effects associated with protonation of $\mathrm{HS}^{-}$and volatilization of $\mathrm{H}_{2} \mathrm{~S}$. Chemical Geology 58, 253-258.

Garten, C.T., 1993. Variation in foliar ${ }^{15} \mathrm{~N}$ abundance and the availability of soil nitrogen on Walker Branch Watershed. Ecology 74 (7), 2098-2113.

Gebauer, G., Schultze, E.-D., 1991. Carbon and nitrogen isotope ratios in different compartments of a healthy and a declining Picea forest in the Fichtelgebirge, NE Bavaria. Oecologia 87, 198-207.

Geist, V., 1999. Deer of the World. Swan Hill Press, Shrewsbury, England.

Högberg, P., 1997. Tansley review $\mathrm{N}^{\circ} 95-15 \mathrm{~N}$ natural abundance in soil-plant systems. New Phytologist 137, 179-203.

Heaton, T.H.E., 1999. Spatial, species, and temporal variations in the ${ }^{13} \mathrm{C} /{ }^{12} \mathrm{C}$ ratios of $\mathrm{C}_{3}$ plants: implications for palaeodiet studies. Journal of Archaeological Science 26, 637-649.

Heptner, V.G., Nasimovitch, A.A., Bannikov, A.G., 1989. In: Mammals of the Soviet Union, vol. 1. Ungulates. E.J. Brill, Leiden.

Hobbie, E., Macko, S.A., Shugart, H.H., 1998. Patterns of N dynamics and N isotopes during primary succession in Glacier Bay, Alaska. Chemical Biology 152, 3-11.

Hobbie, E.A., Jumpponen, A., Trappe, J., 2005. Foliar and fungal ${ }^{15} \mathrm{~N}:{ }^{14} \mathrm{~N}$ ratios reflect development of mycorrhizae and nitrogen supply during primary succession: testing analytical models. Oecologia 146, 258-268.

Hultine, K.R., Marshall, J.D., 2000. Altitude trends in conifer leaf morphology and stable carbon isotope composition. Oecologia 123, 32-40.

Iacumin, P., Bocherens, H., Mariotti, A., Longinelli, A., 1996. Oxygen isotope analyses of co-existing carbonate and phosphate in biogenic apatite: a way to monitor diagenetic alteration of bone phosphate? Earth and Planetary Science Letters $142,1-6$.

Iacumin, P., Nikolaev, V., Ramigni, M., 2000. C and N stable isotope measurements on Eurasian fossil mammals, 40000 to 10000 years BP: herbivore physiologies and palaeoenvironmental reconstruction. Palaeogeography, Palaeoclimatology, Palaeoecology 163, 33-47.

Jenkins, S.G., Partridge, S.T., Stephenson, T.R., Farley, S.D., Robbins, C.T., 2001. Nitrogen and carbon isotope fractionation between mothers, neonates, and nursing offspring. Oecologia 129, 336-341.

Kaplan, I.R., Rittenberg, S.C., 1964. Microbiological fractionation of sulphur isotopes. Journal of General Microbiology 34, 195-212.

Koch, P.L., 2007. Isotopic study of the biology of modern and fossil vertebrates. In: Michener, R., Lajtha, K. (Eds.), Stable Isotopes in Ecology and Environmental Science. Blackwell Publishing, pp. 99-154.

Kohn, M.J., 2010. Carbon isotope compositions of terrestrial C3 plants as indicators of (paleo)ecology and (paleo)climate. Proceedings of the National Academy of Science 107, 19691-19695.

Kohn, M.J., Schoeninger, M.J., Valley, J.W., 1996. Herbivore tooth oxygen isotope compositions: effects of diet and physiology. Geochimica et Cosmochimica Acta 60, 3889-3896

Körner, C., Farquhar, G.D., Wong, S.C., 1991. Carbon isotope discrimination by plants follows latitudinal and altitudinal trends. Oecologia 88, 30-40.

Krouse, H.R., Mayer, B., 2000. Sulphur and oxygen isotopes in sulphate. In: Cook, P., Herczeg, A.L. (Eds.), Environmental Tracers in Subsurface Hydrology. Kluwer Academic Publishers, pp. 195-231.

Longin, R., 1971. New method of collagen extraction for radiocarbon dating. Nature $230,241-242$ 
Longinelli, A., 1984. Oxygen isotopes in mammal bone phosphate: a new tool for paleohydrological and paleoclimatological research? Geochimica et Cosmochimica Acta 48, 385-390.

Lowe, J.J., Rasmussen, S.O., Björck, S., Hoek, W.Z., Steffensen, J.P., Walker, M.J.C., $\mathrm{Yu}, \mathrm{Z}$.C., The INTIMATE group, 2008. Synchronisation of palaeoenvironmental events in the North Atlantic region during the Last Termination: a revised protocol recommended by the INTIMATE group. Quaternary Science Reviews 27, 6-17.

Magny, M., Aalbersberg, G., Bégeot, C., Benoit-Ruffaldi, P., Bossuet, G., Disnar, J.R. Heiri, O., Laggoun-Defarge, F., Mazier, F., Millet, L., Peyron, O., Vannière, B., Walter-Simmonnet, A.V., 2006. Environmental and climatic changes in the Jura mountains (eastern France) during the Lateglacial-Holocene transition: a multiproxy record from Lake Lautrey. Quaternary Science Reviews 25, 414-445.

Männel, T.T., Auerswald, K., Schnyder, H., 2007. Altitudinal gradients of grassland carbon and nitrogen isotope composition are recorded in the hair of grazers. Global Ecology and Biogeography 16, 583-592.

Marino, B.D., McElroy, M.B., Salawitch, R.J., Spaulding, W.G., 1992. Glacial-to-interglacial variations in the carbon isotopic composition of atmospheric $\mathrm{CO}_{2}$. Nature 357, 461-466.

Mariotti, A., Pierre, D., Vedy, J.C., Bruckert, S., 1980. The abundance of natural ${ }^{15} \mathrm{~N}$ in the organic matter of soils along an altitudinal gradient. Catena 7, 293-300.

Morecroft, M.D., Woodward, F.I., 1990. Experimental investigation on the environmental determination of $\delta^{13} \mathrm{C}$ at different altitudes. Journal of Experimental Botany 31, 1303-1308.

Murphy, B.P., Bowman, D.M.J.S., 2006. Kangaroo metabolism does not cause the relationship between bone collagen $\delta^{15} \mathrm{~N}$ and water availability. Functional Ecology 20, 1062-1069.

Nadelhoffer, K.J., Fry, B., 1994. Nitrogen isotope studies in forest ecosystems. In: Lajtha, K., Michener, R.H. (Eds.), Stable isotopes in Ecology and Environmental Science. Blackwell Scientific Publications, Oxford, pp. 22-44.

Nehlich, O., Richards, M.P., 2009. Establishing collagen quality criteria for sulphur isotope analysis of archaeological bone collagen. Archaeological and Anthropological Sciences 1, 59-75.

Nicod, P.-Y., Picavet, R., 2003. La stratigraphie de la Grande Rivoire (Isère, France) et la question de la néolithisation alpine. In: Besse, M., Stahl Gretsch, L.-I., Curdy, P. (Eds.), ConstellaSion. Hommage à Alain Gallay. Cahiers d'Archéologie Romande 95, Lausanne, pp. 147-168.

Novák, M., Buzek, F., Harrison, A.F., Prechová, E., Jacková, I., Fottova, D., 2003. Similarity between C, N and S stable isotope profiles in European spruce forest soils: implications for the use of $\delta^{34} \mathrm{~S}$ as a tracer. Applied Geochemistry 18, 765-779.

Peterson, B.J., Fry, B., 1987. Stable isotopes in ecosystem studies. Annual Review of Ecology and Systematics 18, 293-320.

Pétrequin, P., 1970. La grotte de la Baume de Gonvillars. Annales Littéraires de l'Université de Besançon. Les Belles Lettres, Paris.

Pion, G., 2004. Les occupations humaines au Tardiglaciaire dans les deux Savoie et le Jura méridional. Magdalénien, Epipaléolithique et Mésolithique ancien: cultures, industries, cadre environnemental et fonction des sites. Ph.D. Thesis, Université de Franche-Comté, France.

Pion, G., Mével, L., 2005. Nouvelles recherches sur les occupations tardiglaciaires dans les Alpes du nord françaises: premiers résultats des fouilles de l'abri des Douattes (Musièges, Haute-Savoie). Antiquités Nationales 37, 63-68.

Pion, G., Billard, M., Bintz, P., Caillat, B., Cataliotti-Valdida, J., Durand, J.-M., Girard, M., Monjuvent, G., 1990. L'abri de la Fru à Saint-Christophe (Savoie). Gallia Préhistoire 32, 65-123.

Privat, K.L., O'Connell, T.C., Hedges, R.E.M., 2007. The distinction between freshwater- and terrestrial-based diets: methodological concerns and archaeological applications of sulphur stable isotope analysis. Journal of Archaeological Science 34, 1197-1204.

Reimer, P.J., Baillie, M.G.L., Bard, E., Bayliss, A., Beck, J.W., Blackwell, P.G., Bronk Ramsey, C., Buck, C.E., Burr, G., Edwards, R.L., Friedrich, M., Grootes, P.M., Guilderson, T.P., Hajdas, I., Heaton, T.J., Hogg, A.G., Hughen, K.A., Kaiser, K.F. Kromer, B., McCormac, F.G., Manning, S.W., Reimer, R.W., Richards, D.A., Southon, J., Turney, C.S.M., van der Plicht, J., Weyhenmeyer, C.E., 2009. IntCal09 and Marine09 radiocarbon age calibration curves, $0-50,000$ cal BP. Radiocarbon 51, 1111-1150.

Richard, H., Bégeot, C., 2000. Le Tardiglaciaire du massif jurassien: bilan et perspectives de recherches. Quaternaire 11, 145-154.
Richards, M.P., Fuller, B.T., Hedges, R.E.M., 2001. Sulphur isotopic variation in ancient bone collagen from Europe: implications for human palaeodiet, residence mobility, and modern pollutant studies. Earth and Planetary Science Letters 191, 185-190.

Richards, M.P., Hedges, R.E.M., 2003. Variations in bone collagen $\delta^{13} \mathrm{C}$ and $\delta^{15} \mathrm{~N}$ values of fauna from Northwest Europe over the last 40000 years. Palaeogeography, Palaeoclimatology, Palaeoecology 193, 261-267.

Rossmann, A., Haberhauer, G., Hölzl, S., Horn, P., 2000. The potential of multielement stable isotope analysis for regional origin assignment of butter. European Food Research and Technology 211, 32-40.

Sommer, R.S., Fahlke, J.M., Schmölcke, U., Benecke, N., Zachos, F.E., 2008a. Quaternary history of the European roe deer (Capreolus capreolus). Mammal Review 39, $1-16$

Sommer, R.S., Zachos, F.E., Street, M., Jöris, O., Skog, A., Benecke, N., 2008b. Late Quaternary distribution dynamics and phylogeography of the red deer (Cervus elaphus) in Europe. Quaternary Science Reviews 27, 714-733.

Sponheimer, S., Robinson, T., Ayliffe, L., Roeder, B., Hammer, J., Passey, B., West, A. Cerling, T., Dearing, D., Ehleringer, J., 2003a. Nitrogen isotopes in mammalian herbivores: hair $\delta^{15} \mathrm{~N}$ values from a controlled feeding study. International Journal of Osteoarchaeology 13, 80-87.

Sponheimer, M., Robinson, T., Roeder, B.L., Passey, B.H., Ayliffe, L.K., Cerling, T.E., Dearing, M.D., Ehleringer, J.R., 2003b. An experimental study of nitrogen flux in llamas: is ${ }^{14} \mathrm{~N}$ preferentially excreted? Journal of Archaeological Science 30 $1649-1655$.

Sprent, J.I., 1987. The Ecology of the Nitrogen Cycle. Cambridge University Press, Cambridge.

Stevens, R.E., Hedges, R.E.M., 2004. Carbon and nitrogen stable isotope analysis of northwest European horse bone and tooth collagen, 40,000 BP-present: palaeoclimatic interpretations. Quaternary Science Review 23, 977-991.

Stevens, R.E., Lister, A.M. Hedges, R.E.M. 2006. Predicting diet, trophic level and palaeoecology from bone stable isotope analysis: a comparative study of five red deer populations. Oecologia 149, 12-21.

Stevens, R.E., Jacobi, R., Street, M., Germonpré, M., Conard, N.J., Münzel, S.C. Hedges, R.E.M., 2008. Nitrogen isotope analyses of reindeer (Rangifer tarandus) 45,000 BP to 9,000 BP: palaeoenvironmental reconstructions. Palaeogeography, Palaeoclimatology, Palaeoecology 262, 32-45

Stuart, A.J., Lister, A.M., 2010. Extinction chronology of the cave lion Panthera spelaea. Quaternary Science Reviews. doi:10.1016/j.quascirev.2010.04.023.

Stuart, A.J., Kosintsev, P.A., Higham, T.F.G., Lister, A.M., 2004. Pleistocene to Holocene extinction dynamics in giant deer and woolly mammoth. Nature 431, 684-689.

Thévenin, A., 1982. Rochedane. L'Azilien, l'Epipaléolithique de l'Est de la France et les civilisations épipaléolithiques de l'Europe occidentale. Mémoire de la Faculté des Sciences Sociales, Ethnologie. Université des Sciences humaines, Strasbourg.

Thévenin, A., Sainty, J., 1980. Un gisement préhistorique exceptionnel du Jura alsacien: l'abri du Mannlefelsen I à Oberlag (Haut-Rhin). Annuaire de la Société d'Histoire Sundgauvienne, 21-39.

Tieszen, L.L., 1991. Natural variations in the carbon isotope values of plants: implications for archaeology, ecology, and paleoecology. Journal of Archaeological Science 18, 227-248.

Tütken, T., Vennemann, T.W., Janz, H., Heizmann, E.P.J., 2006. Palaeoenvironment and palaeoclimate of the Middle Miocene lake in the Steinheim basin, SW Germany: a reconstruction from $\mathrm{C}, \mathrm{O}$, and $\mathrm{Sr}$ isotopes of fossil remains. Palaeogeography, Palaeoclimatology, Palaeoecology 241, 457-491.

van der Merwe, N.J., Medina, E., 1991. The canopy effect, carbon isotope ratios and foodwebs in Amazonia. Journal of Archaeological Science 18, 249-259.

Vika, E., 2009. Strangers in the grave? Investigating local provenance in a Greek bronze age mass burial using $\delta^{34} \mathrm{~S}$ analysis. Journal of Archaeological Science 36, 2024-2028.

Voruz, J.-L., Perrin, T., Sordoillet, D., collaborators, 2004. La séquence néolithique de la grotte du Gardon (Ain). Bulletin de la Société préhistorique française 1001 (4), 827-866

Vuaillat, D., Thévenin, A., Heim, J., 1984. Un nouveau gisement épipaléolithique et mésolithique en Franche-Comté: l'abri de Gigot 1 à Bretonvillers (Doubs): note préliminaire. In: Millotte, J.-P. (Ed.), Eléments de Pré et Protohistoire Européenne. Annales Littéraires de l'Université de Besançon. Les Belles-Lettres, Paris pp. 115-124. Hommages au professeur. 